\title{
Key ecological research questions for Central European forests
}

Christian Ammer ${ }^{a, b,}{ }^{*}$, Andreas Fichtner ${ }^{c}$, Anton Fischer ${ }^{d}$, Martin M. Gossnere, Peter Meyer ${ }^{f}$, Rupert Seidls, Frank M. Thomas ${ }^{h}$, Peter Annighöfer ${ }^{\mathrm{a}}$, Jürgen Kreylingi, Bettina Ohse ${ }^{\mathrm{j}, c}$, Uta Berger ${ }^{\mathrm{k}}$, Eike Feldmann', Karl-Heinz Häberle ${ }^{m}$, Katrin Heer ${ }^{n}$, Steffi Heinrichs ${ }^{a}$, Franka Huth ${ }^{\circ}$, Klara Krämer-Klement ${ }^{p}$, Andreas Mölder ${ }^{f}$, Jörg Müller ${ }^{q}$, Martina Mund ${ }^{a}$, Lars Opgenoorth ${ }^{r}$, Peter Schalla, Michael SchererLorenzen ${ }^{\mathrm{s}}$, Dominik Seidel ${ }^{\mathrm{a}}$, Juliane Vogt $^{\mathrm{t}}$, Sven Wagner ${ }^{\circ}$

\section{Author affiliation}

aSilviculture and Forest Ecology of the Temperate Zones, University of Göttingen, Germany

${ }^{b}$ Centre for Biodiversity and Sustainable Land-use, University of Göttingen, Germany

Institute of Ecology, Leuphana University of Lüneburg, Germany

${ }^{\mathrm{d}}$ Geobotany, Technische Universität München, Germany

${ }^{\text {e}}$ Forest Entomology, Swiss Federal Research Institute WSL, Switzerland

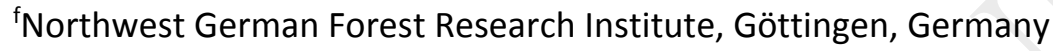

EInstitute of Silviculture, University of Natural Resources and Life Sciences (BOKU), Vienna, Austria

${ }^{\text {h}}$ Geobotany, University of Trier, Germany

'Experimental Plant Ecology, University of Greifswald, Germany

${ }^{j}$ Systematic Botany and Functional Biodiversity, University of Leipzig, Germany

${ }^{\mathrm{k}}$ Forest Biometrics and Forest Systems Analysis, TU Dresden, Tharandt, Germany

'Plant ecology and ecosystems research, University of Göttingen, Germany

mEcophysiology of Plants, Technische Universität München, Germany

${ }^{\mathrm{n}}$ Conservation Biology, Philipps University Marburg, Germany

'Silviculture, Department of Forest Sciences, TU Dresden, Tharandt, Germany

PInstitute for Environmental Research; RWTH Aachen University, Germany

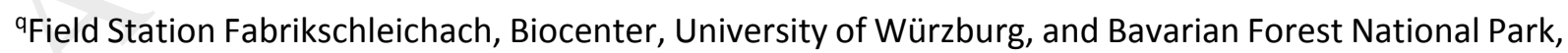
Germany

'Department of Ecology, Philipps University Marburg, Germany

${ }^{\mathrm{s}}$ Geobotany, Faculty of Biology, University of Freiburg, Germany

'Terrestrial Ecology, Technische Universität München, Germany

This document is the accepted manuscript version of the following article:

Ammer, C., Fichtner, A., Fischer, A., Gossner, M. M., Meyer, P., Seid1, R., ... Wagner, S. (2018). Key ecological research questions for Central European forests. Basic and Applied Ecology, 32, 3-25. https://doi.org/10.1016/j.baae.2018.07.006 
*Corresponding author. Tel.: +49 551 3933671; fax: +49 551 3933270

E-mail address: christian.ammer@forst.uni-goettingen.de (Ch. Ammer).

Silviculture and Forest Ecology of the Temperate Zones, Büsgenweg 1, 37077 Göttingen, Germany 


\section{Abstract}

Forests are under pressure from accelerating global change. To cope with the multiple challenges related to global change but also to further improve forest management we need a better understanding of (1) the linkages between drivers of ecosystem change and the state and management of forest ecosystems as well as their capacity to adapt to ongoing global environmental changes, and (2) the interrelationships within and between the components of forest ecosystems. To address the resulting challenges for the state of forest ecosystems in Central Europe, we suggest 45 questions for future ecological research. We define forest ecology as studies on the abiotic and biotic components of forest ecosystems and their interactions on varying spatial and temporal scales. Our questions cover five thematic fields and correspond to the criteria selected for describing the state of Europe's forests by policy makers, i.e. biogeochemical cycling, mortality and disturbances, productivity, biodiversity and biotic interactions, and regulation and protection. We conclude that an improved mechanistic understanding of forest ecosystems is essential for the further development of ecosystem-oriented multifunctional forest management in the face of accelerating global change.

Keywords: Forest Ecology, productivity, mortality, protection, biodiversity, management, conservation

\section{Introduction}

Globally, forests are of crucial importance for climate, biodiversity, and human well-being (Costanza, d'Arge, De Groot, Farber, Grasso et al. 1997). However, forests are under pressure from accelerating global change, including climate change, land-use change and land-use intensification, which affect forest structure, forest functioning, and biodiversity (Bonan, 2008; Sala, Chapin, Armesto, Berlow, Bloomfield et al. 2000). In particular, a further increase in temperature and disturbance probability (Rahmstorf \& Coumou 2011, Thom \& Seidl 2016), a projected decrease in summer precipitation, a possible reduction of areas used for food production and a corresponding increase in area used for biomass production are expected for the coming decades (Schröter, Cramer, Leemans, Prentice, Araújo et al. 2005). It is widely accepted that most goods and services provided by Europe's forests will be impacted by these changes, but not much is known to what extent this will happen and how to quantitatively assess the impact of global change (Lindner, Maroschek, Netherer, Kremer, Barbati, et al. 2010). An improved knowledge of the linkages between the drivers of ecosystem change and the state of nature, the delivery of ecosystem services, and human well-being is of vital importance when managing ecosystems for future generations (Balmford \& Bond, 2005). Revealing these linkages, however, is a difficult task: The high variety of forest ecosystems, the heterogeneity in site conditions even within a specific forest type, and the mutual interactions between the different species in a specific ecosystem require consideration. Consequently, regional to local ecological knowledge is 
needed in order to "influence land-use decisions on a scale at which they are typically made" (Kremen, 2005). This is all the more important when ecosystem services come into play.

Here we are focusing on the temperate nemoral forests of Central Europe, which are particular in many ways. First, under the current climatic conditions one single tree species (Fagus sylvatica) would most likely achieve dominance on a wide range of sites across Central Europe (Bohn, Gollub \& Hettwer 2000; Giesecke, Hickler, Kunkel, Sykes \& Bradshaw 2007; Leuschner \& Ellenberg, 2017).

Second, in Central Europe humans have started to influence the distribution, structure and composition of forests more than 5000 years ago (Schulze, Aas, Grimm, Gossner, Walentowski et al. 2016). This has led to a regionally and temporally fluctuating degree of deforestation particularly during medieval times, with forest cover declining until the early $19^{\text {th }}$ century in many regions (Wedekind 1844; Williams 2000; Kaplan, Krumhardt \& Zimmermann 2009; Radkau 2012). In the last 250 years, Central European temperate forests have been restored but also managed intensively. They are, with very few exceptions, still under management today and affected by the legacies of postglacial recolonization, forest management history, and/or agricultural aftereffects in the case of afforestations (Glatzel, 1991; Dupouey, Dambrine, Laffite \& Moares, 2002; Oheimb, Härdtle, Naumann, Westphal, Assmann et al. 2008; Bebi, Seidl, Motta, Fuhr, Firm et al. 2017; Jiménez-Alfaro, Girardello, Chytrý, Svenning, Willner et al. 2018).

Third, due to the long history of land use, old-growth forests are largely absent in Central Europe. Additionally, the proportion of fast growing conifers has been strongly increased by modern forestry since the $19^{\text {th }}$ century. However, high-intensity industrial plantation forests (i.e. even-aged stands composed of fast growing and often non-native tree species in which trees are harvested in rotation cycles $<50$ years) remain widely absent in Central Europe. After 150 years of favouring conifers at the expense of broadleaves and applying an even-aged management system (partly adopted from agriculture), forest management has shifted during recent decades: In large parts of Central Europe forestry today aims at promoting mixed and structured stands composed of several age/ size cohorts, and the dominating regeneration method has changed from planting to natural regeneration in many places (Bürgi \& Schuler, 2003; Knoke, Ammer, Stimm \& Mosandl, 2008).

Fourth, forest research including long-term monitoring has a long tradition in Central Europe. For example, growth and yield plots still under observation date back to 1870 (Pretzsch, Biber, Schütze, Uhl \& Rötzer 2014). Another example is the International Co-operative Programme on Assessment and Monitoring of Air Pollution Effects on Forests (ICP Forests), which was launched more than 30 years ago and assesses a broad range of environmental conditions (Sanders, Michel \& Ferretti al. 2016). Due to an extensive history of studying different taxa by naturalists, taxonomists, amateur botanists and 
zoologists, knowledge on the ecology of forest-dwelling plant and animal species may be among the best in the world (Ogilvie, 2008).

Finally, the majority of Central European forests are managed for multiple ecosystem services, addressing the diverging interests and societal demands of the large human population in the area. This does neither mean that all ecosystem services (e.g. timber production, soil protection, provision of drinking water and habitat, recreation, biodiversity conservation, etc.) are provided by each stand at the same time (Ammer \& Puettmann, 2009), nor that ecosystem functions are necessarily positively correlated (Byrnes, Lefcheck, Gamfeldt, Griffin, Isbell et al. 2014), but management in Central European forests usually goes beyond maximising a single ecosystem service.

Management for multifunctionality is not straightforward due to many trade-offs between different goals (e. g. Sing, Metzger, Paterson \& Ray 2018). It is further challenged by the impacts of global change, such as climate change, $\mathrm{N}$-deposition, invasive species, changing biotic and abiotic disturbances, homogenization and/or intensification of management practices to name just a few. These challenges affect the state of Central European forests, and subsequently the sustainable provisioning of ecosystem goods and services (Wagner, Nocentini, Huth, \& Hoogstra-Klein, 2014). In order to regularly assess the state of European forests and the development towards Sustainable Forest Management (SFM), the Ministerial Conference for the Protection of Forests in Europe (Forest Europe) has developed a set of criteria and indicators (Forest Europe, 2015). These criteria and the related indicators include (i) the maintenance and appropriate enhancement of forest resources and their contribution to global carbon cycles, (ii) the maintenance of forest ecosystem health and vitality, (iii) the maintenance and encouragement of productive functions of forests, (iv) the maintenance, conservation and appropriate enhancement of biological diversity in forest ecosystems, (v) the maintenance and appropriate enhancement of protective functions in forest management (notably soil and water), and (vi) the maintenance of other socio-economic functions and conditions (Forest Europe 2015). While these criteria help to characterize the state of European forests and its development over time, they cannot answer underlying questions of forest ecosystem functioning, nor can they identify the causes for changes in forest ecosystem properties. Addressing these questions is the realm of forest ecological research, which we here define as studies on the abiotic and biotic components of forest ecosystems and their interactions on varying spatial and temporal scales. Via improving the knowledge on ecosystem processes and functions, forest ecological research provides the fundamental basis for ecosystem-oriented forest management and nature conservation. Thereby forest history and, hence, legacy effects need to be taken into account.

In a recent review, Mori, Lertzman, Gustafsson \& Cadotte (2017) have outlined a forest research agenda focusing on the relationships between biodiversity, ecosystem functioning and ecosystem 
services. Here we extend the scope of this agenda beyond biodiversity relationships, addressing important attributes of five out of the six criteria describing the state of Europe's forests as the fundamental basis for forest policy in Europe. The criteria "maintenance of other socio-economic functions and conditions" does not fall within our definition of forest ecological research and is thus not addressed here. The objective of this opinion paper is to present important questions related to the ecology of Central European forests. We aim to stimulate further research and highlight questions which, once answered, will improve our knowledge of the functioning of Central European forest ecosystems. Based on such an improved mechanistic understanding, ecosystem-oriented forest management and nature conservation strategies may be developed. Although focusing on Central European forests, we believe that the utility of addressing these questions goes considerably beyond our focal systems and will also contribute to our understanding of many other forest types and forest landscapes. Like previous similar papers (Sutherland, Freckleton, Godfray, Beissinger, Benton et al. 2013) we make no claim of completeness. Also, the selection of questions was not generated by majority vote of all Central European forest ecologists, and other consortia certainly would have come up with different questions. Here, our search for important research questions was based on a twostep approach (Fig. 1). First, researchers of the working group "Forest ecology" of the Ecological Society of Germany, Austria and Switzerland (GfÖ) met for a two-day workshop to identify key questions in forest ecological science. During this workshop around 75 questions of varying levels of abstraction were identified, and subsequently condensed to around 40 questions. Second, during the revision process a smaller group of forest ecologists amended, restructured, refocused and harmonised the questions. Through this two-stage process, 45 research questions were identified and grouped along the main criteria selected to describe the state of Europe's forests by policy makers (Forest Europe 2015). The questions are listed at the end of each respective chapter.

\section{Biogeochemical cycling}

Biochemical cycles and their dependency on tree species composition, site conditions and forest developmental stage have been a major subject of forest ecology for many years (Schulze 2000, Galloway, Dentener, Capone, Boyer, Howarth et al. 2004, Bredemeier, Cohen, Godbold, Lode, Pichler et al. 2011). However, as in many other parts of the world, water, nutrient, and carbon cycles of European forests have been strongly influenced by anthropogenic activities in the past (e.g. forest grazing, litter raking, large-scale clear cutting, acidic deposition or conversion of species composition towards conifers, nitrogen deposition, etc.; Leuschner \& Ellenberg 2017). Consequently, understanding the current situation of Central European forests and modelling the future development of their biogeochemical cycles has to consider strong land-use legacies (Bebi, Seidl, Motta, Fuhr, Firm et al. 2017). In addition, climate change in combination with various other manmade modifications of the environment, e. g. changes in nitrogen cycling (Erisman, Galloway, 
Seitzinger, Bleeker, Dise et al. 2013) or the introduction of exotic species, require basic and applied research concerning their consequences for forest functioning (Question 1). Yet, challenges for research on forest functioning in general and on biochemical cycling in particular do not only result from the speed and uncertainty of climate change or the multitude of potential interactions across temporal and spatial scales, but also from our incomplete understanding of basic, ecophysiological processes and how they affect ecosystem properties. Thus, we need a better understanding of the importance of intraspecific variation in ecophysiological and anatomic tree traits. Such an improved knowledge base is particularly relevant in the contexts of adaptation to climate change and the forest carbon cycle (Q 2). It was, for example, shown that genetic differences in drought resistance exist and that tree species known as drought-sensitive have developed strategies to adapt their hydraulic system (Meier \& Leuschner 2008; Schuldt, Knutzen, Delzon, Jansen, Muller-Haubold et al. 2016; Bolte, Czajkowski, Cocozza, Tognetti, de Miguel et al. 2016; Stojnić, Suchocka, Benito-Garzón, Torres-Ruiz, Cochard et al. 2018; Heer, Behringer, Piermattei, Bässler, Brandl et al. 2018). Such knowledge is urgently needed to further develop adaptive management strategies to counter destabilizing effects on forest ecosystems (Ammer 2017; Bolte, Ammer, Löf, Madsen, Nabuurs et al., 2009; Keenan, 2015). We have gained important insights into univariate impacts of many global change drivers on ecosystem processes in forests (e.g. warming, drought, $\mathrm{N}$ deposition, ozone, exotic tree species, pests and pathogens, and management), but we still know little about how they act collectively (Seidl, Thom, Kautz, Martin-Nenito, Peltoniemi et al. 2017; Yue, Fornara, Yang, Peng, Li et al. 2017). The interaction of combined effects could be buffering (Leuzinger, Luo, Beier, Dieleman, Vicca et al. 2011), additive (Yue, Fornara, Yang, Peng, Li et al. 2017) or multiplicative (Dieleman, Vicca, Dijkstra, Hagedorn, Hovenden et al. 2012). Interactions of the various environmental factors need to be investigated across spatio-temporal scales to reveal non-linear system behaviour and to identify tipping points leading to drastic changes of a system, including the loss of resilience (Reyer, Brouwers, Rammig, Brook, Epila et al. 2015; Scheffer, Carpenter, Foley, Folke \& Walker 2001; van Nes, Arani, Staal, van der Bolt, Flores et al. 2016; ; Heer, Behringer, Piermattei, Bässler, Brandl et al. 2018) (Q 3 ).

Stands dominated by one or two tree species are characteristic for large forested areas in Central Europe. Forests consisting of several tree species might generally be more resistant and resilient to disturbances (Pedro, Rammer, \& Seidl 2015; Brockerhoff, Barbaro, Castagneyrol, Forrester, Gardiner et al. 2017). However, mixing tree species also has numerous consequences for biogeochemistry (Pretzsch, Forrester \& Bauhus 2017; Scherer-Lorenzen 2014) via several potential mechanisms. These include spatial (e.g. Meißner, Köhler, Schwendenmann \& Hölscher 2012) and temporal (Jacob, Leuschner \& Thomas 2010, Silvertown, Araya \& Gowing 2015) differences in the resource exploitation of tree species, redistribution of nutrients and carbon compounds via leaf litter (e.g., Guckland, Jacob, 
Flessa, Thomas \& Leuschner 2009) or mycorrhiza (Klein, Siegwolf \& Körner 2016) and decomposition of organic matter (e.g. Jacob, Viedenz, Polle \& Thomas 2010).

However, effects of interspecific tree competition on important functional traits such as rooting patterns and water uptake, remain insufficiently understood (Lei, Scherer-Lorenzen \& Bauhus 2012; Meinzer, Warren \& Brooks 2007; Meißner, Köhler, Schwendenmann \& Hölscher 2012; Thomas, Bögelein \& Werner 2015). For example, differentiation of rooting systems may foster complementary water use via phenomena such as hydraulic lift and hydraulic redistribution (Zapater, Hossann, Bréda, Bréchet, Bonal et al. 2011; Pretzsch, Schütze \& Uhl 2013), improving water availability to shallowrooting species. However, increased belowground competition could also increase drought stress for shallow-rooted species, or may diminish ground water recharge (Grossiord, Granier, Ratcliffe, Bouriaud, Bruelheide et al. 2014). Furthermore, it remains unclear whether responses to climatic conditions differ in native and introduced tree species populations (Chakraborty, Wang, Andre, Konnert, Lexer et al., 2016) (Q 4). In addition, plant-plant and plant-animal interactions and their effects on the carbon and nitrogen cycling of forest ecosystems have recently received increasing attention (Klein, Siegwolf \& Körner 2016; Zieger, Holczinger, Sommer, Rath, Kuzyakov et al. 2017), but are still insufficiently understood (Q 5).

The functioning of forest ecosystems is strongly related to the decomposition and mineralisation of organic matter during biogeochemical cycling. While the principal factors involved in the decomposition of organic matter and their effects on decomposition rates are well known (Prescott 2010), large knowledge gaps still exist regarding the direct and indirect effects of climate change on the decay of organic matter (Suseela \& Tharayil 2018), on the complex interactions between bacteria and fungi in the decomposition process (Bani, Pioli, Ventura, Panzacchi, Borruso et al. 2018), on the role of arthropods for nutrient cycling and forest productivity (Ulyshen 2015; Ulyshen 2016), the interaction of parasites, leaf chemistry, herbivory and decomposition (Künkler, Brandl \& Brändle 2013), and on the effects of the ongoing nitrogen deposition on the mineralisation and storage of carbon compounds in the soil (Averill \& Waring 2018) (Q 6). In this context, it is also of interest to know what role harvest residuals play for the carbon dynamics of mineral soils. Furthermore, there are large areas of forests on organic soils in Europe, many of which have been drained and now emit large amounts of greenhouse gases $\left(>144,000 \mathrm{~km}^{2}\right.$ of peatland drained and currently used in production forestry across Europe; Joosten \& Tanneberger 2017). Strategies for managing these forests require basic understanding of the processes that can restore carbon accumulation. Simply rewetting is not enough as it can cause a complete die-back of trees and create shallow lakes which emit high amounts of methane, rather than resulting in productive forests that sequester carbon (Q 7). 
Many forest stands in Central-Europe are situated on hillslopes or in mountainous terrain. However, in the past most studies on biogeochemical processes have been conducted at homogeneous and flat sites. Matter and energy fluxes between soil, vegetation and the atmosphere may well differ on slopes (Matyssek, Wieser, Patzner, Blaschke \& Häberle 2009). The differentiation of forest stands in heterogeneous landscapes is thus important, and can be addressed through a combination of terrestrial and air-born approaches (Stoffels, Hill, Sachtleber, Mader, Buddenbaum et al. 2015). Remote sensing, monitoring of C-flow between atmosphere and ecosystem (Lyssaert, Ciais, Piao, Schulze, Jung et al. 2010) and ecosystem modelling were successfully used to study terrestrial carbon cycling. These approaches combine spatially continuous information (remote sensing) and model carbon cycling over various temporal scales (Turner, Ollinger, \& Kimball 2004). The integration of structural data with ecosystem process models and climate data may pave the way towards a regional assessment of carbon fluxes and the analysis of the underlying processes (Seidl, Spies, Rammer, Steel, Pabst et al. 2012; Turner, Ollinger, \& Kimball 2004) (Q 8). At a smaller scale, the importance of heterogeneity within forest stands for biochemical processes (e.g. McLaughlin, Ackerly, Klos, Natali, Dawson et al. 2017) needs to be more thoroughly addressed in forest ecosystem research (Q 9).

\section{Questions}

Q1 In which direction and how rapidly will biogeochemical cycling change under the current and future rates of climate change and eutrophication?

Q 2 How large is the morphological and physiological plasticity of tree species and provenances in the face of climate change, eutrophication and their interaction?

Q 3 How large is the combined effect of climatic stressors on the biogeochemical cycling in forest ecosystems?

Q 4 Are biogeochemical cycles in diverse forests more resistant and resilient towards climatic changes and eutrophication?

Q 5 How do plant-plant and plant-animal interactions influence biogeochemical cycling in forest ecosystems?

Q 6 How do climate change and eutrophication influence the interaction of microorganisms and soil arthropods and their role in biogeochemical cycling?

Q7 What are the main drivers of the forest soil carbon balance, what is the role of harvest residuals in managed forests on organic soils, and which role do soil organisms play for storing and stabilizing carbon in soils?

Q 8 How can we reliably determine fluxes of matter and energy in spatially heterogeneous forested landscapes?

Q 9 To what extent does small-scale spatial heterogeneity impact biogeochemical cycling in forest ecosystems? 


\section{Mortality and disturbances}

Due to their complex architecture both above- and belowground, the physical structures in forests are unique among terrestrial ecosystems. Consequently, forest structure is an important focus of research, not least because of the strong relationship of forest structures to the functions and services forests provide (e.g. Lindbladh, Lindström, Hedwall \& Felton 2017; Lindenmayer \& Franklin 1997). As forest structure can be actively modified through management interventions, it is also a central element of forest management (Motta \& Lingua 2005; Bauhus, van der Meer \& Kanninen 2010; Parviainen, Bücking, Vandekerkhove, Schuck, \& Päivinen 2000; Messier, Puettmann, Chazdon, Andersson, Angers et al., 2015; Schall, Schulze, Fischer, Ayasse, \& Ammer 2018). A key process affecting the structure and demography of forests apart from forest management is natural tree mortality. Tree mortality is a complex process and the factors leading to the death of a tree can either come in sudden events, called disturbances, or can unfold over decades, e.g., by fungal infestation (Holzwarth, Kahl, Bauhus \& Wirth 2013; Hartmann, Schuldt, Sanders, Macinnis-Ng, Boehmer et al. 2018).

The ultimate reason for death of individual trees - besides mechanical damage - remains unclear (Schweingruber \& Wirth, 2009) (Q 10). For example, there is no consensus as to whether cavitation and conductivity loss of the xylem or carbon starvation (or both) cause tree mortality under drought conditions (Sevanto, McDowell, Dickman, Pangle \& Pockman 2014). Furthermore, ageing in plants differs from animals especially due to their high degree of meristem integrity (Thomas, 2013; Sarkar, Schmid-Siegert, Iseli, Calderon, Gouhier-Darimont et al., 2017). An improved mechanistic understanding of the maximum attainable age of trees is needed, as it also has implications for the provisioning of ecosystem services. Old-growth forests constitute important carbon stores and continue to take up carbon (Stephenson, Das, Condit, Russo, Baker et al., 2014), but the longevity of trees and their maximum growth rates are inversely related (Bugmann \& Bigler, 2011). In addition, the carbon allocation within trees and their response to external drivers change with tree age (Genet, Bréda, \& Dufrêne 2010) (Q 11). A better understanding of these processes is of high importance for making robust projections of future forest ecosystem dynamics (Bircher, Cailleret, \& Bugmann, 2015). As tree mortality is a natural process in forests, dead trees are a typical element of healthy ecosystems. However, mortality is also highly sensitive to many drivers of global change (e.g., changes in climate, changes in forest structure and composition), making it an important topic of research for current forest ecology, also in ecosystems strongly altered by humans (Hartmann, Adams, Anderegg, Jansen, \& Zeppel 2015; Neumann, Mues, Moreno, Hasenauer \& Seidl, 2017). The signal of climate change, for instance, differs among seasons. It also influences the length of the growing season (Menzel \& Fabian 1999). Plant responses to the environmental conditions of a specific season, however, can have implications for other seasons such as insufficient frost hardening triggered by warm autumn temperatures, potentially reducing winter frost tolerance (Malyshev, Henry, Bolte, Arfin Khan \& 
Kreyling, 2017). Paradoxically, this can lead to increased mortality from frost despite the general warming trend (Augspurger 2013; Fisichelli, Vor, \& Ammer, 2014) (Q 12).

Disturbance can be defined as any discrete event through which live plant biomass is lost (Begon, Harper \& Townsend, 1996). This includes both abiotic (especially important in the temperate forests of Europe are windstorm, fire, snow avalanches) and biotic events (such as pests including insect outbreaks and diseases). The temporal duration of these events is short in relation to the length of the processes involved (i.e., the life-span of a tree) and they are clearly spatially differentiated from undisturbed areas (Fischer, Marshall, \& Camp, 2013). Disturbances can vary from small-scale events resulting in the loss of patches of trees up to landscape-scale events. Although much is known about stand properties and environmental conditions that increase the susceptibility to disturbances, we still lack an understanding of the natural sizes and frequencies of these events in Central Europe and their impact on forest structure and composition (Seymour, White \& deMaynadier 2002; Nagel, Svoboda \& Kobal 2014; Svoboda, Janda, Bače, Fraver, Nagel et al. 2014, Janda, Trotsiuk, Mikoláš, Bače, Nagel et al. 2017) (Q 13).

Currently, harvesting is the most important and pervasive disturbance in Europe's temperate forests. Because of the forest history of the region (Parviainen, 2005) we largely lack areas which can serve as reference for forest structures and natural disturbance dynamics without human impact. Remaining old-growth forests, such as those of the mountain regions of Central and Eastern Europe, are important sources for studying the natural disturbance regimes of the past (Svoboda, Janda, Bače, Fraver, Nagel et al. 2014; Čada, Morrissey, Michalová, Bače, Janda, et. al. 2016; Schurman, Trotsiuk, Bače, Čada, Fraver et al. 2018). Recent findings suggest, for instance, that intermediate wind disturbances occurred at time intervals similar to or less than the life expectancy of most canopy tree species in Central Europe, and may play a more important role in forest dynamics than previously thought (Nagel \& Diaci, 2006; see also Jaloviar, Saniga, Kucbel, Pittner, Vencurik et al., 2017; Petritan, Bouriaud, Frank, \& Petritan 2017). How the historic range of variability compares to the current (and future) disturbance regime is an important remaining question for the temperate forest ecosystems of Europe (Kulakowski, Seidl, Holeksa, Kuuluvainen, Nagel et al. 2017) (Q 14). This question is particularly important in the context of climate-mediated changes in disturbance regimes (Seidl, Thom, Kautz, Martin-Nenito, Peltoniemi et al. 2017), as the assessment of any change process requires a robust baseline.

In addition to putting disturbance regimes in their historical context, it is of high relevance to better understand the impacts of disturbances. Remote sensing allows the assessment of variability in forest structure (size differentiation) or the estimation of other biophysical structures such as canopy rugosity (Bolton, Coops, Hermosilla, Wulder, \& White, 2017; Clark \& Clark, 2000; Simard, Pinto, Fisher \& Baccini, 
2011) and their effects on forest functioning (e.g. Coops, Hermosilla, Hilker \& Black, 2017) in response to different disturbances (e.g. White, Wulder, Hermosilla, Coops \& Hobart, 2017) (Q 15).

Tree mortality in the future will differ from the past; many studies suggest a potential increase in tree mortality for the coming decades (Trumbore, Brando \& Hartmann, 2016; Seidl, Thom, Kautz, MartinNenito, Peltoniemi et al. 2017). Climate change is, for instance, expected to amplify drought in many forest ecosystems (Allen, Breshears \& McDowell, 2015). In addition disturbances from wind, wildfire, and insects are expected to increase in the temperate forest ecosystems of Europe (Seidl, Schelhaas, Rammer \& Verkerk, 2014). Thus, climate change will strongly alter tree mortality regimes. Improved simulation models are needed to make more robust projections on potential future trajectories of ecosystems under emerging future disturbance regimes. In addition to changes in native disturbance agents novel agents of tree death, such as invasive alien pests and pathogens, are increasingly introduced by global trade. In temperate North-America exotic insect pests and pathogens are estimated to be the most serious threat to forest health and ecosystem processes (Lovett et al. 2006). For Europe's temperate forests, comparable estimates are widely lacking, yet examples such as Dutch elm disease (Karnosky 1979) and the dieback of European ash (Pautasso, Aas, Queloz, \& Holdenrieder, 2013) illustrate the severity of the threat. In addition to alien pests and pathogens, also alien plant species can be a threat to the health and integrity of forest ecosystems. In North-America, for instance, Ehrenfeld, Kourtev and Huang (2001) have shown that invasive plant species are able to change soil functions. In this particular case invasive plant species seem to be driven by invasive earthworms (Nuzzo, Maerz, \& Blossey, 2009). Furthermore, the interaction between invasive species and global warming is likely to further aggravate the issue (Seidl, Klonner, Rammer, Essl, Moreno et al. 2018) and impact abiotic and biotic ecosystem properties (Eisenhauer, Fisichelli, Frelich, \& Reich 2012). A better understanding of the emerging future forest mortality regimes (consisting of both, native and alien agents) is needed to assess potential consequences on ecosystem structure and functioning ( $\mathbf{Q} \mathbf{1 6})$.

\section{Questions}

Q 10 Why does a tree die?

Q 11 Which traits are conferring longevity, and how is longevity modulated by environmental factors?

Q 12 How do trees respond to changes in seasonality?

Q 13 At which intervals do small and large-scale disturbances occur naturally in the forest ecosystems of Central Europe, and which pattern of forest succession do they create at the landscape scale?

Q 14 How do the current and projected future disturbance regimes (and the ecosystem structures emerging from them) compare to the historical range of variability?

Q 15 What is the effect of different mortality patterns and processes on ecosystem functioning? 
Q 16 What future mortality regimes are emerging from climate change and the introduction of alien species?

\section{Productivity}

Forests play an important role in providing ecosystem services such as wood production. Although forest productivity increased during the last century in Central European forests (Pretzsch, Biber, Schütze, Uhl \& Rötzer, 2014), ongoing global environmental changes (e.g. climate change and anthropogenic nitrogen deposition) can impose significant variation in wood production (Lindner, Maroschek, Netherer, Kremer, Barbati et al., 2010). Numerous studies have demonstrated that increasing temperatures and altered precipitation regimes can lead to growth decline or forest dieback across the globe (e.g. Allen, Macalady, Chenchouni, Bachelet, McDowell et al., 2010; O'Brien, Engelbrecht, Joswig, Pereyra, Schuldt et al., 2017). However, the co-occurring effects between climate extremes and nitrogen deposition remain poorly understood (Lindenmayer, Likensa, Krebs, \& Hobbs, 2010; Greaver, Clark, Compton, Vallano, Talhelm et al., 2016). For example, recent work showed that climate-induced growth decline is amplified by nitrogen fertilization (Dziedek, Härdtle, von Oheimb, \& Fichtner, 2016; Braun, Schindler \& Rihm, 2017; Hess, Niemeyer, Fichtner, Jansen, Kunz et al. 2018). According to the 'Optimal Partitioning Theory', plants should allocate carbon to the organ acquiring the most limiting resource (Shipley \& Meziane, 2002; McCarthy \& Enquist, 2007). Thus, an improved understanding of processes including drought-induced shifts in above- and belowground allocation patterns and nutrient cycling will improve our ability to predict changes in forest productivity (Q 17, Q 18).

In addition to the physiological response of trees (see also $\mathbf{Q} 2$ ), forest structure and tree species composition have been identified as important factors in determining how forest productivity will respond to climate change (Coomes, Flores, Holdaway, Jucker, Lines et al., 2014; Ruiz-Benito, MadrigalGonzález, Ratcliffe, Coomes, Kändler et al., 2014). The structural characteristics of a forest depend on a variety of factors such as natural disturbances, climate, stand development stage, species composition and forest management (e.g. Messier, Puettmann, Chazdon, Andersson, Angers et al., 2015; Bebi, Seidl, Motta, Fuhr, Firm et al., 2017). For example, structural attributes such as stand basal area, leaf area index (LAI) or canopy space filling are important attributes of forest productivity (Reich 2012; Juchheim, Ammer, Schall, \& Seidel, 2017) and closely linked to resource availability (e.g. soil moisture; Gebhardt, Häberle, Matyssek, Schulz \& Ammer, 2014). It may be conceivable that belowground complementarity leads to higher aboveground biomass, which in turn could improve light interception (Niklaus, Baruffol, He, Ma, \& Schmid 2017; Ammer 2018). However, it remains unclear to what extent structurally diverse forests shape resource availability and forest functions under changing climatic conditions (Q 19). 
There is increasing evidence that productivity is often positively related to diversity in tree morphology, species or functional traits (e.g. Paquette \& Messier 2011; Zhang, Chen, \& Reich, 2012; Dănescu, Albrecht \& Bauhus, 2016; Liang, Crowther, Picard, Wiser, Zhou et al. 2016). Several mechanisms have been proposed for the observed diversity-productivity relationships (for reviews see Scherer-Lorenzen 2014, Forrester \& Bauhus 2016, Grossman, Vanhellemont, Barsoum, Bauhus, Bruelheide et al. 2018; Ammer 2018), and positive net diversity effects are often summarized as 'complementarity effects' (Forrester \& Bauhus 2016). Such effects can be attributed to niche partitioning, which can lead to competitive reduction, and facilitation (Grossman, Vanhellemont, Barsoum, Bauhus, Bruelheide et al. 2018). For example, by disentangling tree-tree interactions recent work provided evidence that competitive reduction and facilitation are critically determined by the functional traits of the target tree (Fichtner, Härdtle, Li, Bruelheide, Kunz, \& von Oheimb 2017). However, it remains largely unclear whether positive diversity effects are mainly driven by competitive reduction or facilitation, what role functional diversity plays (Q 20), and how productivity patterns change with stand development (Q 21). Maintaining structurally complex and functionally diverse forests also seems to be a promising approach to mitigate the impact of climate change on forest productivity. Although tree species richness has been shown to positively affect forest productivity at the global scale (Liang, Crowther, Picard, Wiser, Zhou et al., 2016), we still largely lack an integrated understanding of how tree diversity effects on productivity will vary with climate (but see Jucker, Avăcăriței, Bărnoaiea, Duduman, Bouriaud et al., 2016; Paquette, Vayreda, Coll, Messier, \& Retana, 2017; Ruiz-Benito, Ratcliffe, Jump, Gómez-Aparicio, Madrigal-González et al., 2017). For example, we do not know under which conditions climate change will shift the existing species interactions in forest ecosystems from complementarity effects sensu Loreau (2000) towards systems where the selection effect prevails, or vice versa (Ammer 2018) (Q 22). As both the diversity of forest structure and composition critically depend on forest management, mixing tree species and promoting structurally diverse stands are important measures for mitigating climate change effects on forest productivity (Ammer, 2017). Moreover, 'active adaptation measures' include the introduction of highly productive and drought-tolerant non-native tree species such as Douglas-fir (Pseudotsuga menziesii; Spellmann, Weller, Brang, Michiels, \& Bolte, 2015) but it remains unclear whether climate responses differ in native and introduced populations (Chakraborty, Wang, Andre, Konnert, Lexer et al., 2016).

Legacy effects of land-use have been shown to determine nutrient cycling in forests due to altered soil microbial communities (Fraterrigo, Balser \& Turner, 2006; Fichtner, von Oheimb, Härdtle, Wilken \& Gutknecht, 2014). Accordingly, recent studies have stressed the importance of land-use legacies on the response of forests to global environmental change (Johnstone, Allen, Franklin, Frelich, Harvey et al., 2016; Perring, De Frenne, Baeten, Maes, Depauw et al., 2016), but empirical evidence remains limited (but see Mausolf, Härdtle, Jansen, Delory, Hertel et al. 2018) (Q 23). Improving our 
understanding of how tree diversity affects forest productivity and of how drivers of global environmental change interact with forest structure, tree diversity and legacy effects are therefore vital for assessing the future trajectories of forest productivity.

\section{Questions}

Q 17 How important are weather patterns and climatic extremes for the productivity of trees?

Q 18 To what extend do climatic changes affect above- and belowground biomass allocation patterns in forest stands?

Q 19 How is structural diversity linked to resource availability and forest productivity?

Q 20 Which functional traits are key to the diversity-productivity relationship?

Q 21 How does the diversity-productivity relationship vary with stand development and tree ontogeny?

Q 22 Can climate change shift diversity-productivity relationships from being dominated by complementarity effects to selection effects or vice versa?

Q 23 How do drivers of global change interact with land-use legacies to shape forest productivity?

\section{Biodiversity and biotic interactions}

Forests comprise a large proportion of Central Europe's biodiversity and its protection is an important objective in forest policy and management (Forest Europe 2015). However, it needs to be considered that the current state of forest biodiversity in Central Europe is a result of interacting intrinsic dynamics and human land-use (Kirby \& Watkins, 1998; Bengtsson, Nilsson, Franc \& Menozzi, 2000). Thus, we need to understand the natural processes driving forest biodiversity as well as the relationships between different components of management, forest structure and biodiversity. Biodiversity comprises different facets including species richness, diversity, identity, and composition as well as genetic, functional, structural, ecosystem, and landscape diversity. These facets might be differently affected by environmental drivers. Moreover, the diversity and functional composition of communities and the biotic interactions within and across trophic levels are considered a fundamental element of forest ecosystem functionality (Hooper, Adair, Cardinale, Byrnes, Hungate et al., 2012; Soliveres, van der Plas, Manning, Prati, Gossner et al., 2016), as they mediate ecosystem processes and services (Scherer-Lorenzen, Körner, \& Schulze, 2005; Mori, Lertzman, Gustafsson \& Cadotte, 2017), such as water and nutrient cycling (Scherer-Lorenzen, 2014), or pest control (Jactel, Brockerhoff \& Duelli, 2005). For effective conservation a more detailed understanding of the important drivers of biodiversity and biotic interactions at different temporal and spatial scales is crucially needed.

Tree individuals provide habitat for a large number of organisms spanning several orders of magnitude in body size (Brändle \& Brandl, 2001; Strätz, Wagner \& Müller, 2009; Wagner, Wehnert, Wong \& Stoyan, 2016). The driving factors, i.e. the relevant tree traits providing ecological niches as well as the 
importance of habitat continuity (Ohlson, Söderström, Hörnberg, Zackrisson \& Hermansson, 1997; Nordén, Dahlberg, Brandrud, Fritz, Ejrnaes et al., 2014; Janssen, Fuhr, Cateau, Nusillard, \& Bouget, 2017) and connectivity (Fahrig, 2013; Seibold, Bässler, Brandl, Fahrig, Förster et al., 2017) remain only partly understood. Moreover, recent studies have stressed the importance of intraspecific trait variability at different trophic levels for the adaptive ability of species to environmental change as well as for their effects on ecosystem processes (Ali, Reineking \& Münkemüller, 2017; De Bello, Lavorel, Albert, Thuiller, Grigulis et al., 2011; Hulshof, Violle, Spasojevic, McGill, Damschen et al., 2013; Lepš, de Bello, Šmilauer \& Doležal, 2011). For instance our understanding of how inter-individual genetic and physiological variation of trees impact the assemblage of associated organisms is still far from being complete (Gossner, Simons, Achtziger, Blick, Dorow, 2015; Hughes, Inouye, Johnson, Underwood \& Vellend, 2008; Whitham, Gehring, Lamit, Wojtowicz, Evans, et al., 2012) (Q 24). This also relates to the fact that intra-specific variability is not systematically reflected in common trait databases for plants (Kattge, Diaz, Lavorel, Prentice, Leadley et al., 2011) and animals (Homburg, Schuldt, Drees \& Assmann, 2013; Gossner, Simons, Achtziger, Blick, Dorow, 2015). Future studies should focus on the importance of intraspecific trait variability for species interactions and resulting ecosystem processes (Q 25). Additionally, spatial effects of fragmentation, habitat loss and the surrounding matrix on biodiversity need to be better understood to develop efficient conservation strategies (Huxel \& Hastings 1999; Widerberg Koch, Ranius, Drobyshev, Nilsson \& Lindbladh, 2012; Müller, Bae, Röder, Chao, \& Didham, 2014; Humphrey, Watts, Fuentes-Montemayor, Macgregor, Peace et al., 2015) (Q 26). In the face of climate change the question arises how tree species might adapt to changing conditions at larger spatial scales, and whether forest managers should select for particular genotypes in species in response to these changes (Rose, Leuschner, Köckemann \& Buschmann, 2009; Weber, Bugmann, Pluess, Walthert \& Rigling, 2013). This could affect tree genetic diversity and associated organisms and their interactions (Q 27).

Biodiversity is strongly influenced by abiotic site conditions (Keddy 2017) as well as resource availability ('More Individuals Hypothesis', Srivastava \& Lawton, 1998) and heterogeneity ('Resource Heterogeneity Hypothesis', Hutchinson, 1959). The available evidence on the relative importance of these mechanisms is, however, inconclusive and thus more studies disentangling these mechanisms are needed. Forest structure and hence forest management largely determine the abiotic and biotic conditions that are important for biodiversity. The relevance of forest structure for biodiversity has been demonstrated for various species groups over several decades (MacArthur \& MacArthur, 1961; Karr \& Roth, 1971; Gerell, 1988; Paillet, Berges, Hjältén, Odor, Avon et al., 2010; Kraus \& Krumm, 2013; Schall, Gossner, Heinrichs, Fischer, Boch et al., 2018). Beyond the current state of knowledge, however, we need a better understanding of key structural attributes (from microhabitats to the landscape scale) for biodiversity, their proper quantification (Zenner, \& Hibbs, 2000; Neumann \& Starlinger, 2001; 
Pommerening, 2002; Seidel, 2018; Schall, Schulze, Fischer, Ayasse, \& Ammer 2018) and how they should temporally and spatially be arranged to foster biodiversity (Drobyshev, Niklasson, Linderson, Sonesson, Karlsson et al., 2008) (Q 28, Q 29). For example, several approaches have been suggested on how to integrate key features of old-growth forests into managed forests (Aubry, Halpern \& Peterson, 2009; Gustafsson, Kouki \& Sverdrup-Thygeson, 2010; Gustafsson, Baker, Bauhus, Beese, Brodie et al., 2012). However, not much is known about how fast retention trees develop microhabitats (Vuidot, Paillet, Archaux, \& Gosselin, 2011; Larrieu, Cabanettes, Gonin, Lachat, Paillet et al. 2017) and over which distances they might help to promote biodiversity. In this context the role of habitat amount ('Habitat-amount Hypothesis') vs. spatial arrangements ('Habitat-patch Hypothesis') of key structural attributes such as habitat trees and dead wood is important, and strongly relies on the dispersal ability of focal species (Fahrig 2003; Komonen \& Müller 2018). So far only a limited number of studies addressed these questions for Central European forests (Schall, Gossner, Heinrichs, Fischer, Boch et al., 2018; Seibold, Bässler, Brandl, Fahrig, Förster et al., 2017). For an evaluation of the most effective conservation strategy, we need well-designed studies aiming at disentangling the relative importance of habitat area, habitat quality, as well as spatial and temporal connectivity for biodiversity. Ultimately this may lead to the question whether or not conservation strategies in nature reserves should consider interventions shaping habitat heterogeneity, e.g. by considering the mixed disturbance severity concept (Mikoláš, Svitok, Bollmann, Reif, Bače et al., 2017), or enhancing the restoration of old-growth attributes (Bauhus, Puettmann \& Messier, 2009).

Homogenization of ecosystems by land-use is a main driver of biodiversity loss (Gamez-Virues, Perovic, Gossner, Borschig, Bluthgen et al., 2015; Gossner, Lewinsohn, Kahl, Grassein, Boch et al. 2016; McKinney \& Lockwood 1999; van der Plas, Ratcliffe, Ruiz-Benito, Scherer-Lorenzen, Verheyen et al., 2016). Ecosystems may be homogenized by land-use intensification or land-use equalization. Land-use intensification in Central European forests is characterized by decreasing the age, size, and biomass of tree populations through harvests, as well as by altering the tree species composition compared to the natural vegetation (Schall \& Ammer 2013). In contrast to other regions of the world, interventions like fertilization, pesticide application and soil preparation are negligible in Central European forests (Ammer, Balandier, Bentsen, Coll, \& Löf, 2011), and will most likely remain an exception due to public pressure, at least in the near future. Land-use equalization, in contrast, reduces the diversity of landuse practices irrespective of their intensity, leading to a convergence of the structure and composition of forests at the landscape scale (Beese \& Bryant, 1999). Current forest management guidelines and certification criteria (FSC Working Group Germany, 2012) promote land-use equalization by favouring a single management system, in Central Europe a fine-grained continuous cover forestry regime (Messier, Puettmann, Chazdon, Andersson, Angers et al., 2015). In the past the impact of forest management systems on biodiversity was focused on alpha-diversity along a land-use intensity 
gradient or between different forest management interventions (Paillet, Berges, Hjältén, Odor, Avon et al., 2010). It is, however, necessary to also consider entire silvicultural systems including different developmental stages, tree species identities and mixtures types at different spatial scales (Q $\mathbf{3 0}$ ). Therefore, research should be directed towards a landscape approach by considering different scales of diversity (alpha, beta, gamma), different diversity metrics (species richness, species and functional diversity and composition) as well as species interactions. This will result in a better mechanistic understanding (e.g. biotic and abiotic filtering) of the management-diversity-ecosystem relationships, and can form the basis for improved forest management strategies (e.g. Edwards, Gilroy, Woodcock, Edwards, Larsen et al., 2014, van der Plas, Manning, Allan, Scherer-Lorenzen, Verheyen et al., 2016; Schall, Gossner, Heinrichs, Fischer, Boch et al., 2018).

Disturbance in natural forest systems can vary between small-scale events resulting in the loss of single trees up to landscape-scale disturbances caused by factors such as storm, fire, pests and pathogens (Turner, 2010). The 'Intermediate Disturbance Hypothesis' (Connell, 1978) suggests that overall biodiversity peaks at intermediate disturbance levels (Roxburgh, Shea, \& Wilson 2004), as different taxonomic and functional groups respond differently to disturbances. However, this theory has been contested recently (Fox, 2013) and the effects of disturbances on biodiversity across spatial and temporal scales (Belote, Sanders, \& Jones, 2009) remain incompletely understood (Winter, Ammer, Baier, Donato, Seibold, et al., 2015; Winter, Bässler, Bernhardt-Römermann, Krah, Schaefer, et al., 2017; Thom, Rammer, Dirnböck, Müller, Kobler et al. 2017) (Q 31). A better understanding of how different organisms react to disturbance is needed to predict how extreme events (Mann, Rahmstorf, Kornhuber, Steinman, Miller et al., 2017) may shape our forests in an uncertain future (Seidl, Thom, Kautz, Martin-Nenito, Peltoniemi et al. 2017). Understanding the importance of successional as well as disturbance-driven natural dynamics for biodiversity can further help to develop effective forest management strategies. Preferentially natural dynamics are studied in primeval forests, but these have virtually been eradicated from Central Europe in the past (Parviainen, 2005). Strict forest reserves allow establishing gradients of forest-use intensity and studying the impact of natural and anthropogenic disturbances on biodiversity (Müller, Hothorn, \& Pretzsch, 2007; Paillet, Berges, Hjältén, Odor, Avon et al., 2010; Winter, Flade, Schumacher, Kerstan, \& Möller, 2005). As set-aside areas are only an incomplete substitute for primeval forests, we additionally need to more intensively make use of the remaining primeval forest in, e.g. the Carpathians for studying how biodiversity is shaped by varying disturbances at different spatial scales (Q 31). In combination with studying disturbance events such as windthrows and wildfires in managed landscapes, new avenues for forest management might be opened by considering such disturbances as part of a dynamic integrative approach (Bollmann \& Braunisch 2013). However, a better mechanistic understanding of the succession of species and the recovery processes following disturbance events is important; here 
recently developed trait- and phylogenetic based approaches are promising (Cadotte, Albert, \& Walker, 2013). Among biotic drivers of forest dynamics, pest outbreaks (e.g. bark beetles) and the introduction of alien pathogens such as Hymenoscyphus fraxineus (causing ash dieback) and the emerald ash borer (Agrilus planipennis) might become increasingly important, in particular in combination with climate change and the resultant drought stress. In order to support forest adaptation to climate change cultivating non-native drought-tolerant tree species such as Douglas-fir is frequently discussed in Central Europe (Bolte, Ammer, Löf, Madsen, Nabuurs et al. 2009). How such active (including host associated species) and passive introductions will influence biodiversity and biotic interactions and the resulting processes is still debated (Q $\mathbf{3 2}$ ).

To improve the state of Central European forests in the context of biodiversity, the role of past and present forest management needs to be addressed in more detail. Specifically, ownerships and land tenure as well as land-use legacies need to be considered more explicitly (Q $\mathbf{3 3}, \mathbf{Q} \mathbf{3 4})$. For systematic conservation planning, e.g. of priority sites for conservation, knowledge on disturbance and management history of potential areas is crucial (Lachat \& Bütler, 2009; Hannon, Niklasson, Brunet, Eliasson, \& Lindbladh, 2010, Flensted, Bruun, Ejrnæs, Eskildsen, Thomsen et al., 2016). Historical ecology helps to elucidate this dimension and provides guidance for future management (Szabó \& Hédl, 2011). Management intensity or traditional management techniques are known to be closely linked to forest ownership type (Flensted, Bruun, Ejrnæs, Eskildsen, Thomsen et al., 2016; Johann \& Schaich 2016, Mölder 2016, Cervellini, Fiorini, Cavicchi, Campetella, Simonetti et al., 2017). The long life-span of trees results in lag effects of past management and ongoing climate change on future biodiversity-related processes in forests (Hermy \& Verheyen, 2007; Fichtner, von Oheimb, Härdtle, Wilken \& Gutknecht, 2014; Thom, Rammer, Dirnböck, Müller, Kobler et al., 2017). Legacy effects of land-use have been shown to determine the diversity and composition of above- (e.g. Flinn \& Vellend 2005; Hermy \& Verheyen 2007) and belowground communities (e.g. Fraterrigo, Balser \& Turner, 2006; Fichtner, von Oheimb, Härdtle, Wilken \& Gutknecht, 2014) in forests and, thus, affect ecosystem functioning (Q 33). However, the interactive effects between land-use legacies and drivers of global environmental change and their consequences for forest biodiversity and species interactions remain poorly understood (Q 34).

\section{Questions}

Q 24 How do the genetic and physiological differences within and among tree species affect other organisms and species interactions?

Q 25 How does intraspecific variability in tree traits affect intraspecific trait diversity in consumer guilds and ecosystem processes?

Q 26 How do tree species characteristics and traits affect the diversity of organisms living on trees and what is the spatial extent to which single-tree-effects on biodiversity stretch? 
Q 27 How is biodiversity affected by tree species adaptations to climate change and by selection of particular genotypes by forest managers?

Q 28 Which are key structural attributes related to biodiversity at different spatial scales (single trees, forest stands, landscapes), and what are their temporal dynamics?

Q 29 How does the spatial and temporal arrangement of microhabitats and habitat patches affect biodiversity and how important is this compared to habitat amount?

Q 30 To which extend, and how, is regional gamma-diversity of organismic groups controlled by landscape-scale forest structure and composition and what are the relative contributions of different forest types (respectively silvicultural systems, forest developmental phases, etc.) to regional gamma-diversity?

Q 31 How important are varying disturbance size and severity for biodiversity on different spatial scales?

Q 32 Which effect do active introductions of alien tree species (including their associated species) and passive invasion of species have on biodiversity and species interactions? How do these effects interact with land-use and climate change?

Q 33 What is the importance of past management, ownership, and land tenure relative to present management intensity in affecting biodiversity and biotic interactions?

Q 34 How do drivers of global change interact with management and land-use legacies to shape the diversity and composition of forest communities at different scales?

\section{Regulation and protection}

The regulation of important ecosystem fluxes such as the water cycle and the protection of humans against natural hazards are important ecosystem services of forests (for climate regulation see the section on biogeochemical cycling). In addition, forests also protect soils from the eroding forces of wind, water, and gravity. As intact soils are a prerequisite for healthy forests (and the sustainable provisioning of ecosystem services), the regulation and protection functions are of integral importance for the future of forests in Europe.

More than 25 million ha of forests are dedicated to soil protection and water regulation in Europe and an additional 3 million ha are protecting humans and their infrastructure from natural hazards (Forest Europe, 2015). The spatial variation in the importance of these forest functions is considerable, with water quality being especially relevant in densely populated areas and protection being particularly important in mountain areas with high relief energy. While the regulation and protection functions of forests have long been a focus of forest ecology and management in mountain areas, they are often only implicitly regarded as co-benefits of other functions in the stewardship of many other forest ecosystems (Forest Europe, 2015). This raises the question of multifunctionality, and under which 
contexts and conditions regulation and protection are positively correlated with other functions and services (Q 35). Recent analyses indicate a high potential for multifunctionality in Europe's forests (van der Plas, Ratcliffe, Ruiz-Benito, Scherer-Lorenzen, Verheyen et al. 2018) yet ecological context plays an important modifying role (Ratcliffe, Wirth, Jucker, van der Plas, Scherer-Lorenzen, et al. 2017), and trade-offs between functions are frequently reported in local studies (Lafond, Cordonnier, Mao, \& Courbaud, 2017; Langner, Irauschek, Perez, Pardos, Zlatanov et al., 2017).

The relationship between many attributes of forest ecosystems and the regulation and protection functions they provide is highly non-linear. Water transpiration and outflow, for instance, change nonlinearly with leaf area (Pötzelsberger, \& Hasenauer, 2015), and protection against natural hazards changes disproportionally with gap size and stem density (Rammer, Brauner, Ruprecht, \& Lexer, 2015). Many of these relationships have long been known and are phenomenologically well described (e.g. Frehner, Wasser, \& Schwitter, 2005). Yet, our process understanding of how forest structure and composition influences regulation and protection remains incomplete ( $\mathbf{Q} 36)$. A conclusive mechanistic explanation of how diversity in traits and species bolsters regulating functions is still lacking. Furthermore, whether thresholds of forest structure required to provide protection functions (e.g., in terms of minimum stem number and dbh) frequently applied in management (e. g. Frehner, Wasser, \& Schwitter, 2005) are generally applicable across systems and contexts remains to be conclusively tested. Understanding the underlying mechanisms of how forest structure and composition are related to regulation and protection is also an important prerequisite of scaling these functions from the stand to the landscape and regional scale.

Addressing spatial scales beyond the stand scale is important, as many regulation and protection functions provide ex situ ecosystem services (i.e., services that are not consumed where they are provided; Millennium Ecosystem Assessment, 2005). The full functionality of forests in providing protection and regulation can thus only be considered at spatial scales beyond the stand scale (Laudon, Kuglerová, Sponseller, Futter, Nordin et al. 2016). The efficiency of a given forest structure and composition to protect against snow avalanches, for instance, strongly increases with a stand's proximity to the avalanche's place of origin. Consequently, the configuration of a landscape (i.e., the spatial arrangement of different land-use types) is an important factor contributing to regulation and protection (Lamy, Liss, Gonzalez, \& Bennett, 2016). The variable contribution of individual stands to the overall functioning of a forest landscape harbours great potential for improved forest management (Seidl, Albrich, Thom, \& Rammer, 2018), yet the effects of landscape configuration and composition on regulation and protection remain incompletely understood ( $Q$ 37).

Compared to other forest functions, continuity is an aspect of paramount importance in the context of regulation and protection. If the production function, for instance, is reduced for a few years, the 
negative effects, e.g., on forest $C$ storage, can be compensated by improved tree growth in the following years. In contrast, losing the functionality to protect against erosion even for a short period of time can result in substantial loss of soil and subsequent regeneration failure. Temporal stability is thus a crucial element for the regulating and protecting functions of forests; it depends on the sensitivity of forest ecosystems to external drivers, but also on their ability to quickly recover their functionality (Wohlgemuth, Schwitter, Bebi, Sutter \& Brang, 2017). Stability is increasingly challenged by the growing variability and uncertainty induced by global change. Adaptive management strategies considering the potential future changes in climate, $\mathrm{N}$ deposition, and atmospheric $\mathrm{CO}_{2}$ are thus needed (Bolte, Ammer, Löf, Madsen, Nabuurs et al., 2009; Keenan, 2015) in order to ensure a stable regulation and protection function of forests also in the future (Q 38). Increasing natural disturbances can, for instance, affect the water quality and quantity provided by forest ecosystems (Beudert, Bässler, Thorn, Noss, Schröder et al., 2015; Buma \& Livneh, 2017). However, also legacies from past land-uses (e.g. forest grazing, litter raking, large-scale clear-cuttings, acidic deposition, and the conversion towards conifer-dominated forests; Leuschner \& Ellenberg, 2017) still influence forests and their functioning in Europe. The temporal prevalence of these legacies remains still poorly quantified to date. Also, these legacies have the potential to modulate the sensitivity of regulation and protection to drivers of global change, e.g., where past developments created disequilibria in stand age and structure, which now result in elevated disturbance risk (Bebi, Seidl, Motta, Fuhr, Firm et al. 2017; Schurman, Trotsiuk, Bače, Čada, Fraver et al. 2018). The effect of legacies on the current and future provisioning of regulation and protection functions thus requires further attention in research (Q 39). Another factor potentially influencing the regulation and protection functions of forests are ungulates. It is well documented by a large number of studies across the northern hemisphere that high ungulate densities can have drastic effects on tree species composition and stand development, and hence on the regulation and protection functions of forests (Gill 1992; Ammer 1996; Motta 1996; Fuller \& Gill 2001; Rooney 2001; Reimoser 2003; Kupferschmid \& Bugmann 2005; Pellerin, Saïd, Richard, Hamann, Dubois-Coli, et al. 2010). High ungulate densities can even result in detrimental effects on soil fertility (Prietzel \& Ammer 2008), but not much is known about how these different effects of ungulates will be altered by climate change (Didion, Kupferschmid, Wolf \& Bugmann 2011; Cailleret, Heurich \& Bugmann 2014). Only recently large predators such as wolf and lynx have started to recolonize Central Europe, where they now occur in a habitat characterized by an overabundance of ungulate populations and a strongly fragmented landscape. It remains to be shown if and to what extent the returning large predators will change ungulate densities as well as behaviour, and how such changes will affect tree recruitment and the regulation and protection functions of forests (Q 40).

\section{Questions}


Q 35 Under which conditions and contexts are regulation and protection functions generated as cobenefits from other functions (multifunctionality), and where do trade-offs between functions exist?

Q 36 Which structural attributes and tree species traits confer regulation and protection functions, and what are the underlying mechanisms?

Q 37 What is the contribution of individual stands to landscape-level functioning, and how does the configuration and composition of a landscape affect the regulation and protection functions provided by forest ecosystems?

Q 38 How can temporal stability in the regulation and protection functions be achieved in the face of accelerating global change?

Q 39 How strongly are the current regulation and protection functions determined by legacies of past land-use and forest development, and how are legacy effects interacting with drivers of global change?

Q 40 How will the large predators returning to Central Europe affect ungulate densities and behaviour, and will the effect help to restore natural patterns of tree regeneration, fostering regulation and protection functions?

\section{Outlook}

The research questions of the five domains described above are connected in many ways. For example, the effects of mixing tree species is not only of interest with regard to productivity but also with regard to the regulation and protection functions of forests, the diversity of associated organisms in forests and their biochemical cycling (Q 4, Q 20, Q 21, Q 36). Actually, it was shown that multifunctionality may be best achieved through diverse stands (van der Plas, Manning, Allan, Scherer-Lorenzen, Verheyen et al. 2016). This example illustrates that many of the questions listed above are worth being addressed in both managed and unmanaged forests. Another example is related to stand structure. It is not well understood to what extent and how spatial heterogeneity within stands affects biochemical cycles, productivity, biodiversity, resistance towards stressors and regulation functions $(\mathbf{Q} \mathbf{8}, \mathbf{Q} \mathbf{1 9}$, Q 28, Q 36). Even less is known about the importance of spatial heterogeneity at the landscape scale. These two examples highlight that the complexity of forest ecosystems can rarely be adequately addressed by strict disciplinary approaches. In contrast, progress in revealing underlying mechanisms (as opposed to correlative descriptions) will only be achieved by fostering cross-disciplinary exchange. Another way of linking key questions of ecological research is along ecological concepts, such as the functional trait approach (Violle, Navas, Vile, Kazakou, Fortunel, et al. 2007). There is increasing evidence that functional diversity or the presence, abundance, distribution, and diversity of functional traits is more important for ecosystem functioning than species diversity per se (e.g. Díaz, Fargione, 
Chapin \& Tilman, 2006; Nadrowski, Wirth \& Scherer-Lorenzen, 2010; Gagic, Bartomeus, Jonsson, Taylor, Winqvist et al., 2015). Functional traits reflect adaptations to variation in the physical and biotic environment as well as trade-offs (ecophysiological and/or evolutionary) among different functions within an organism (De Bello, Lavorel, Díaz, Harrington, Cornelissen et al., 2010). As species functional traits determine their response to environmental pressures (response traits) and these are linked to traits affecting species interactions and ecosystem processes (effect traits), the consequences of global change depend on the strength of alteration in these interacting functional traits. Therefore, functional traits have received increasing attention in plant and animal ecology recently. However, in forest ecosystems, response and effect traits have rarely been studied together and across trophic levels. Consequently, little is known about the mechanisms, synergisms, and antagonisms that may explain the observed effects on ecosystem functioning (Lavorel \& Granier, 2002; Lavorel, Storkey, Bardgett, de Bello, Berg et al., 2013). Functional traits are thus a promising concept for linking disciplines and questions (Q 20, Q 25, Q 26, Q 36).

A third element that links different ecological questions is scale. While some questions address the individual tree scale (Q 11, Q 12, Q 25, Q 26), most of the questions highlighted here focus on the stand and/or the landscape scale. Forest management mainly operates at the stand scale. This is why studies carried out at this scale may be directly considered for adjusting silvicultural approaches. A good example is the growing evidence of the importance of deadwood for biodiversity (e. g. Müller \& Bütler, 2010; Seibold, Bässler, Brandl, Büche, Szallies et al., 2016), which resulted in clear recommendations for forest practice. As a consequence, public forest administrations in Central Europe have issued instructions how to deal with habitat trees, aiming at minimum amounts of at least $20-30 \mathrm{~m}^{3} \mathrm{ha}^{-1}$ of deadwood.

To improve the linkages between subfields within forest ecology we do need an intensified exchange among the different methodological approaches (monitoring, comparative studies, experiments, models) and scales. This is particularly important in forest research because of the longevity of trees as the main entities of analysis. Without exploring the importance of patterns and processes on small scales for larger entities, and without integrating approaches operating at fine scales and testing to what extent the findings can be scaled up, our mechanistic understanding of forest ecosystem dynamics will hardly improve. In other words, we need to consider different spatial and temporal scales, acknowledging that processes of interest are usually affected by mechanisms acting at scales above and below the focal scale. For most forests in Central Europe, dynamics and functioning cannot be fully understood and/or mechanistically described without taking their history as well as the current land tenure and management regime into account. In this regard, the forests of Central Europe are the epitome of coupled human and natural systems (Liu, Dietz, Carpenter, Alberti, Folke, et al. 2007) and are very well suited to study ecological processes that are tightly entwined with anthropogenic 
processes. Consequently, questions addressing legacy effects are pertinent across research areas (Q 23, Q 33, Q 34, Q 39).

Many of the above-mentioned questions and challenges require long-term ecological research, including monitoring approaches and experiments (Dovers, Norton, \& Handmer, 1996; Simberloff, 1999). Only long-term research will allow us to detect drivers that may ultimately threaten the integrity of forest ecosystems. The most prominent example in this regards is climate change, which fundamentally affects all aspects of forest ecosystem functioning. The importance of climate change and the related uncertainties for forest ecosystem patterns and processes are reflected by the fact that nearly one third of all research questions highlighted here touch issues related to climate change

\section{( $Q$ 1, Q 2, Q 3, Q 6, Q 14, Q 16, Q 17, Q 18, Q 27, Q 32, Q 38, Q 39).}

Understanding the response of forest ecosystems to different drivers and the underlying mechanisms is crucial in the context of forest ecosystem services, and points towards the societal importance of forest ecological research beyond mere curiosity and an interest in natural processes. This requires inter- and transdisciplinary research because ecology and society affect each other through various positive and negative feedbacks. Against this background, future research needs to be matched with social demands and findings need to be better communicated with policy makers (Andersson, Feger, Hüttl, Kräuchi, Mattsson et al., 2000; Farwig, Ammer, Annighöfer, Baur, Behringer et al., 2017). Interdisciplinary approaches are, for instance, needed to test how highly productive non-native tree species added to a matrix of native species alter ecosystem functioning and biodiversity. Tackling such a question requires interdisciplinary work on the same sites to elucidate the processes and organisms influenced by such an introduction. Another example is the integration of trees into agricultural systems in order to reduce negative impacts of agricultural land-use (e.g., on biodiversity) and simultaneously increase economic flexibility. Transdisciplinary approaches are needed to address questions frequently asked by forest managers, such as: Which forest management strategies can minimize negative effects on biodiversity or even promote it, and to what extend would society be willing to cover additional costs of management to compensate for income losses? Another question clearly requiring transdisciplinarity is how large predators can be re-integrated in a highly fragmented and intensively used forested landscape (Breitenmoser 1998). Additionally, scientists need to increasingly engage in the science-policy transfer, even if such activities do not increase scientific reputation (Müller \& Opgenoorth 2014). In fact, the growing complexity and uncertainty seem to have rather complicated the communication between ecologists and society (Dovers, Norton, \& Handmer, 1996). However, policy makers usually only address crucial problems if they know what is at stake and how integrative solutions could look like. 
An intensified transfer of findings from forest ecological research to forest management is also urgently needed. Sustainable forest management in a broader sense needs to be flexible enough to address the demands of future generations, which may differ from present needs (Wagner 2004). That is why answering the questions highlighted here is not only of interest from a scientific point of view, but also could promote improved forest management regimes. For example, for protecting biodiversity and the provision of regulation and protection functions it is not known, which size class distribution of areas that were set aside from forest interventions, yields optimal results. To answer such questions appropriate monitoring is needed which may be integrated in existing European forest monitoring networks. This illustrates that in addition to questions of fundamental ecological understanding also various applied questions are of high relevance for future forest ecological research in Central Europe. Five of them are listed in the following:

Q 41 How effective are conservation measures such as habitat tree retention, setting aside small unmanaged patches etc. for species spreading and hence nature conservation?

Q 42 How should key conservation measures be temporally and spatially arranged at the landscape scale to most effectively protect biodiversity?

Q 43 How can the growing demand for wooden biomass be met in a sustainable manner?

Q 44 How can disturbances be positively integrated in forest management systems?

Q 45 How can large predators be integrated into a fragmented and densely populated landscape?

Forest management depends on an improved mechanistic understanding of ecosystem functioning in order to allow future generations to "respond adaptively to future changes and cope with surprises, potentially providing multiple options" (Mori, Lertzman, Gustafsson \& Cadotte, 2017, page 12). Future research focusing on the concrete questions identified here may enable the development of scientifically sound and flexible forest management and conservation strategies in the face of accelerating global change. In addition, they could deepen our knowledge of forest ecosystems, and could interest a next generation of ecologists for the captivating field of forest ecology.

\section{Acknowledgements}

We are very grateful for constructive criticism on a previous version of the manuscript by Jan Bengtsson, Kris Verheyen and two other anonymous reviewers. This article was initiated during a meeting of the working group 'Forest Ecology' of the Ecological Society of Germany, Austria and Switzerland (Gesellschaft für Ökologie, GfÖ) in April 2017 in Göttingen. The workshop was kindly supported by the Centre for Biodiversity and Sustainable Land-Use of the University of Göttingen. R. Seidl acknowledges support from the Austrian Science Fund (FWF) through START grant Y895-B25.

\section{References}


Allen, C. D., Macalady, A. K., Chenchouni, H., Bachelet, D., McDowell, N., Vennetier, M., ... \& Cobb, N. (2010). A global overview of drought and heat-induced tree mortality reveals emerging climate change risks for forests. Forest Ecology and Management, 259, 660-684.

Allen, C.D., Breshears, D.D. \& McDowell, N.G. (2015). On underestimation of global vulnerability to tree mortality and forest die-off from hotter drought in the Anthropocene. Ecosphere, 6, 1-55.

Ali, H.E., Reineking, B., \& Münkemüller, T. (2017). Effects of plant functional traits on soil stability: intraspecific variability matters. Plant and Soil, 411, 359-375.

Ammer, C. (1996). Impact of ungulates on structure and dynamics of natural regeneration of mixed mountain forests in the Bavarian Alps. Forest Ecology and Management, 88, 43-53.

Ammer, C. (2017). Unraveling the importance of inter-and intraspecific competition for the adaptation of forests to climate change. In: Canovas, F.M., Lüttge, U., \& Matyssek, R. (Eds.), Progress in Botany Vol. 78 (pp. 345-367). Berlin: Springer.

Ammer, C. (2018). Diversity and forest productivity in a changing climate. New Phytologist, doi: 10.1111/nph.15263

Ammer, C., Balandier, P., Bentsen, N.S., Coll, L., \& Löf, M. (2011). Forest vegetation management under debate: an introduction. European Journal of Forest Research, 130, 1-5.

Ammer, C., \& Puettmann, K. (2009). Waldbau, quo vadis? - Waldbewirtschaftung zwischen Funktionenorientierung und Multifunktionalität. Forstarchiv, 80, 90-96.

Andersson, F. O., Feger, K.-H., Hüttl, R. F., Kräuchi, N., Mattsson, L., Sallnäs, O., \& Sjöberg, K. (2000). Forest ecosystem research - priorities for Europe. Forest Ecology and Management, 132, 111-119.

Aubry, K. B., Halpern, C. B., \& Peterson, C. E. (2009). Variable-retention harvests in the Pacific Northwest: A review of short-term findings from the DEMO study. Forest Ecology and Management, $258,398-408$.

Augspurger, C.K. (2013). Reconstructing patterns of temperature, phenology, and frost damage over 124 years: Spring damage risk is increasing. Ecology, 94, 41-50.

Averill, C., \& Waring, B. (2018). Nitrogen limitation of decomposition and decay: How can it occur? Global Change Biology, 24, 1417-1427.

Balmford, A., \& Bond, W. (2005). Trends in the state of nature and their implications for human wellbeing. Ecology Letters, 8, 1218-1234.

Bani, A., Pioli, S., Ventura, M., Panzacchi, P., Borruso, L., Tognetti, R., ... \& Brusetti, L. (2018). The role of microbial community in the decomposition of leaf litter and deadwood. Applied Soil Ecology, doi: https://doi.org/10.1016/i.apsoil.2018.02.017

Bauhus, J., Puettmann, K. \& Messier, C. (2009). Silviculture for old-growth attributes. Forest Ecology and Management, 258, 525-537. 
Bauhus, J., van der Meer, P. J., \& Kanninen, M. (Eds.) (2010). Ecosystem goods and services from plantation forests. London: Earthscan.

Bebi, P., Seidl, R., Motta, R., Fuhr, M., Firm, D., Krumm, F., ... \& Kulakowski, D. (2017). Changes of forest cover and disturbance regimes in the mountain forests of the Alps. Forest Ecology and Management, 388, 43-56.

Beese, W.J., \& Bryant, A.A. (1999). Effect of alternative silvicultural systems on vegetation and bird communities in coastal montane forests of British Columbia, Canada. Forest Ecology and Management, 115, 231-242.

Begon, M., Harper J. \& Townsend, C.R. 1996: Ecology. Individuals, populations and communities. Blackwell, 3. ed., $1068 \mathrm{~S}$.

Belote, R. T., Sanders, N.J., \& Jones, R.H. (2009). Disturbance alters local-regional richness relationships in Appalachian forests. Ecology, 90, 2940-2947.

Bengtsson, J., Nilsson, S. G., Franc, A., \& Menozzi, P. (2000). Biodiversity, disturbances, ecosystem function and management of European forests. Forest Ecology and Management, 132, 39-50.

Beudert, B., Bässler, C., Thorn, S., Noss, R., Schröder, B., Dieffenbach-Fries, H., ... \& Müller, J. (2015). Bark beetles increase biodiversity while maintaining drinking water quality. Conservation Letters, 8 , 272-281.

Bircher, N., Cailleret, M., \& Bugmann, H. (2015). The agony of choice: different empirical mortality models lead to sharply different future forest dynamics. Ecological Applications, 25, 1303-1318.

Bohn, U., Gollub, G., \& Hettwer, C. (2000). Karte der natürlichen Vegetation Europas. Bonn: Bundesamt für Naturschutz.

Bollmann, K. \& Braunisch, V. (2013). To integrate or to segregate: balancing commodity production and biodiversity conservation in European forests. In: D. Kraus and F. Krumm (Eds.), Integrative approaches as an opportunity for the conservation of forest biodiversity. In Focus - Managing Forests in Europe (pp. 18-31). Freiburg: European Forest Institute.

Bolte, A., Ammer, C., Löf, M., Madsen, P., Nabuurs, G.J., Schall, P., ... \& Rock, J. (2009). Adaptive forest management in central Europe: Climate change impacts, strategies and integrative concept. Scandinavian Journal of Forest Research, 24, 473-482.

Bolte, A., Czajkowski, T., Cocozza, C., Tognetti, R., de Miguel, M., Pšidová, E., ... \& Müller, J. (2016). Desiccation and Mortality Dynamics in Seedlings of Different European Beech (Fagus sylvatica L.) Populations under Extreme Drought Conditions. Frontiers in Plant Science, 7, 751.

Bolton, D. K., Coops, N.C., Hermosilla, T., Wulder, M.A., \& White, J.C. (2017). Assessing variability in post-fire forest structure along gradients of productivity in the Canadian boreal using multi-source remote sensing. Journal of Biogeography, 10, 405. 
Bonan, G. B. (2008). Forests and climate change: Forcings, feedbacks, and the climate benefits of forests. Science, 320(5882), 1444-1449.

Brändle, M., \& Brandl, R. (2001). Species richness of insects and mites on trees: expanding Southwood. Journal of Animal Ecology, 70, 491-504.

Braun, S., Schindler, C., \& Rihm, B. (2017). Growth trends of beech and Norway spruce in Switzerland: The role of nitrogen deposition, ozone, mineral nutrition and climate. Science of the Total Environment, 599-600, 637-646.

Bredemeier, M., Cohen, S., Godbold, D.L., Lode, E., Pichler, V., \& Schleppi, P. (2011). Forest Management and the Water Cycle. Springer, Dordrecht etc.

Breitenmoser, U. (1998). Large predators in the Alps: the fall and rise of man's competitors. Biological Conservation, 83, 279-289.

Brockerhoff, E.G., Barbaro, L., Castagneyrol, B., Forrester, D.I., Gardiner, B., González-Olabarria, ... \& Jactel, H. (2017). Forest biodiversity, ecosystem functioning and the provision of ecosystem services. Biodiversity and Conservation, 26, 3005-3035.

Bürgi, M., \& Schuler, A. (2003). Driving forces of forest management-an analysis of regeneration practices in the forests of the Swiss Central Plateau during the $19^{\text {th }}$ and $20^{\text {th }}$ century. Forest Ecology and Management, 176, 173-183.

Bugmann, H., \& Bigler, C. (2011). Will the $\mathrm{CO}_{2}$ fertilization effect in forests be offset by reduced tree longevity? Oecologia, 165, 533-544.

Buma, B., \& Livneh, B. (2017). Key landscape and biotic indicators of watersheds sensitivity to forest disturbance identified using remote sensing and historical hydrography data. Environmental Research Letters, 12, 074028.

Byrnes, J., Lefcheck, J. S., Gamfeldt, L., Griffin, J. N., Isbell, F., \& Hector, A. (2014). Multifunctionality does not imply that all functions are positively correlated. Proceedings of the National Academy of Sciences of the United States of America, 111, E5490.

Čada, V., Morrissey, R. C., Michalová, Z., Bače, R., Janda, P., \& Svoboda, M. (2016). Frequent severe natural disturbances and non-equilibrium landscape dynamics shaped the mountain spruce forest in central Europe. Forest Ecology and Management, 363, 169-178.

Cadotte, M., Albert, C.H. \& Walker, S.C. (2013). The ecology of differences: assessing community assembly with trait and evolutionary distances. Ecology Letters, 16, 1234-1244.

Cailleret, M., Heurich, M. \& Bugmann, H. (2014). Reduction in browsing intensity may not compensate climate change effects on tree species composition in the Bavarian Forest National Park. Forest Ecology and Management, 328, 179-192. 
Cervellini, M., Fiorini, S., Cavicchi, A., Campetella, G., Simonetti, E., Chelli, S., ... \& Gimona, A. (2017). Relationships between understory specialist species and local management practices in coppiced forests - Evidence from the Italian Apennines. Forest Ecology and Management, 385, 35-45.

Chakraborty, D., Wang, T., Andre, K., Konnert, M., Lexer, M.J., Matulla, C., ... \& Schueler, S. (2016). Adapting Douglas-fir forestry in Central Europe: evaluation, application, and uncertainty analysis of a genetically based model. European Journal of Forest Research, 135, 919-936

Clark, D. B., \& Clark, D. A. (2000). Landscape-scale variation in forest structure and biomass in a tropical rain forest. Forest Ecology and Management, 137, 185-198.

Connell, J.H. (1978). Diversity in tropical rain forests and coral reefs - high diversity of trees and corals is maintained only in a non-equilibrium state. Science, 199, 1302-1310.

Coomes, D.A., Flores, O., Holdaway, R., Jucker, T., Lines, E.R., \& Vanderwel, M.C. (2014).Wood production response to climate change will depend critically on forest composition and structure. Global Change Biology, 20, 3632-3645.

Coops, N.C., Hermosilla, T., Hilker, T., \& Black, T.A. (2017). Linking stand architecture with canopy reflectance to estimate vertical patterns of light-use efficiency. Remote Sensing of Environment, 194, 322-330.

Costanza, R., d'Arge, R., de Groot, R., Farber, S., Grasso, M., Hannon, B., ... \& van den Belt (1997). The value of the world's ecosystem services and natural capital. Nature, 387(6630), 253-260.

Dănescu, A., Albrecht, A.T. \& Bauhus, J. (2016). Structural diversity promotes productivity of mixed, uneven- aged forests in southwestern Germany. Oecologia, 182, 319-333.

De Bello, F., Lavorel, S., Albert, C. H., Thuiller, W., Grigulis, K., Dolezal, J., ... \& Lepš J. (2011). Quantifying the relevance of intraspecific trait variability for functional diversity. Methods in Ecology and Evolution, 2, 163-174.

De Bello, F., Lavorel, S., Díaz, S., Harrington, R., Cornelissen, J. H. C., Bardgett, R. D., ... \& Harrison, P. A. (2010). Towards an assessment of multiple ecosystem processes and services via functional traits. Biodiversity Conservation, 19, 2873-2893.

Díaz, S., Fargione, J., Chapin, F.S. III \&Tilman, D. (2006). Biodiversity loss threatens human well-being. PLoS Biology, 4, e277.

Didion, M., Kupferschmid, A. D., Wolf, A., \& Bugmann, H. (2011). Ungulate herbivory modifies the effects of climate change on mountain forests. Climatic Change, 109, 647-669.

Dieleman, W. I. J., Vicca, S., Dijkstra, F. A., Hagedorn, F., Hovenden, M. J., Larsen, K. S., ... \& Janssens, I. A. (2012). Simple additive effects are rare: a quantitative review of plant biomass and soil process responses to combined manipulations of $\mathrm{CO}_{2}$ and temperature. Global Change Biology, 18, 26812693. 
Dovers, S. R., Norton, T. W., \& Handmer, J. W. (1996). Uncertainty, ecology, sustainability and policy. Biodiversity and Conservation, 5, 1143-1167.

Drobyshev, I., Niklasson, M., Linderson, H., Sonesson, K., Karlsson, M., Nilsson, S. G., \& Lanner, J. (2008). Lifespan and mortality of old oaks - combining empirical and modelling approaches to support their management in Southern Sweden. Annals of Forest Science, 65, 401-401.

Dupouey, J. L., Dambrine, E., Laffite, J. D., \& Moares, C. (2002). Irreversible impact of past land use on forest soils and biodiversity. Ecology, 83, 2978.

Dziedek, C., Härdtle, W., von Oheimb, G., \& Fichtner, A. (2016). Nitrogen addition enhances drought sensitivity of young deciduous tree species. Frontiers in Plant Science, 7, 1100.

Edwards, D.P., Gilroy, J.J., Woodcock, P., Edwards, F.A., Larsen, T.H., Andrews, D. J. R., ... \& Wilcove, D.S. (2014). Land-sharing versus land-sparing logging: reconciling timber extraction with biodiversity conservation. Global Change Biology, 20, 183-191.

Ehrenfeld, J. G., Kourtev, P., \& Huang, W. (2001). Changes in soil functions following invasions of exotic understory plants in deciduous forests. Ecological Applications, 11, 1287-1300.

Eisenhauer, N., Fisichelli, N. A., Frelich, L. E., \& Reich, P. B. (2012). Interactive effects of global warming and 'global worming' on the initial establishment of native and exotic herbaceous plant species. Oikos, 121, 1121-1133.

Erisman, J.W.; Galloway, J.N.; Seitzinger, S.; Bleeker, A.; Dise, N.B.; Petrescu, R.; ... \&de Vries, W. (2013). Consequences of human modification of the global nitrogen cycle. Philosophical transactions of the Royal Society of London, Series B: Biological sciences, 368 (1621).

Fahrig, L. (2003). Effects of habitat fragmentation on biodiversity. Annual Review of Ecology, Evolution, and Systematics, 34, 487-515.

Fahrig, L. (2013). Rethinking patch size and isolation effects: the habitat amount hypothesis. Journal of Biogeography, 40, 1649-1663.

Farwig, N., Ammer, C., Annighöfer, P., Baur, B., Behringer, D., Diekötter, T., ... \& Ziegenhagen, B. (2017). Bridging science and practice in conservation: Deficits and challenges from a research perspective. Basic and Applied Ecology, 24, 1-8.

Fichtner, A., Härdtle, W., Li, Y., Bruelheide, H., Kunz, M., \& von Oheimb, G. (2017). From competition to facilitation: how tree species respond to neighbourhood diversity. Ecology Letters, 20, 892-900.

Fichtner, A., von Oheimb, G., Härdtle, W., Wilken, C., \& Gutknecht, J.L.M. (2014). Effects of anthropogenic disturbances on soil microbial communities in oak forests persist for more than 100 years. Soil Biology \& Biochemistry, 70, 79-87.

Fischer, A., Marshall, P., \& Camp, A. (2013). Disturbances in deciduous temperate forest ecosystems of the northern hemisphere: their effects on both recent and future forest development. Biodiversity and Conservation, 22, 1863-1893. 
Fisichelli, N., Vor, T., \& Ammer, C. (2014). Broadleaf seedling responses to warmer temperatures "chilled" by late frost that favors conifers. European Journal of Forest Research, 133, 587-596.

Flensted, K. K., Bruun, H. H., Ejrnæs, R., Eskildsen, A., Thomsen, P. F., \& Heilmann-Clausen, J. (2016). Red-listed species and forest continuity - A multi-taxon approach to conservation in temperate forests. Forest Ecology and Management, 378, 144-159.

Flinn, K.M. \& Vellend, M. (2005). Recovery of forest plant communities in post-agricultural landscapes. Frontiers in Ecology and the Environment, 3, 243-250.

Forest Europe (2015). State of Europe's Forests 2015. Ministerial Conference on the Protection of Forests in Europe.

Forrester, D.I., \& Bauhus, J. (2016): A review of processes behind diversity - productivity relationships in forests. Current Forestry Reports, 2, 45-61.

Fox, J. W. (2013). The intermediate disturbance hypothesis should be abandoned. Trends in Ecology \& Evolution, 28, 86-92.

Fraterrigo, J.M., Balser, T.C., \& Turner, M.G. (2006). Microbial community variation and its relationship with nitrogen mineralization in historically altered forests. Ecology, 87, 570-579.

Frehner, M., Wasser, B., \& Schwitter, R. (2005). Nachhaltigkeit und Erfolgskontrolle im Schutzwald. Wegleitung für Pflegemassnahmen in Wäldern mit Schutzfunktion, Vollzug Umwelt. Bundesamt für Umwelt, Wald und Landschaft, Bern, 564 p.

FSC Working Group Germany (2012). German FSC-Standard and Small Forest Standard. FSC-STD-DEU02-2012. https://ic.fsc.org/en/certification/national-standards/europe-russia/germany / Accessed $\underline{03.03 .16 .}$

Fuller, R. J., \& Gill, R. M. (2001). Ecological impacts of increasing numbers of deer in British woodland. Forestry, 74, 193-199.

Gagic, V., Bartomeus, I., Jonsson, T., Taylor, A., Winqvist, C., Fischer, C., ... \& Bommarco, R. (2015). Functional identity and diversity of animals predict ecosystem functioning better than speciesbased indices. Proceedings of the Royal Society of London, Series B: Biological Sciences, 282 (1801), 20142620.

Galloway, J. N., Dentener, F. J., Capone, D. G., Boyer, E. W., Howarth, R. W., Seitzinger, S. P. ... \& Vörösmarty C.J. (2004). Nitrogen cycles: past, present, and future. Biogeochemistry, 70, 153-226.

Gamez-Virues, S., Perovic, D.J., Gossner, M.M., Borschig, C., Bluthgen, N., de Jong, H., ... \& Westphal, C. (2015). Landscape simplification filters species traits and drives biotic homogenization. Nature Communications, 6, 8568.

Gebhardt, T., Häberle, K. H., Matyssek, R., Schulz, C., \& Ammer, C. (2014). The more, the better? Water relations of Norway spruce stands after progressive thinning. Agricultural and forest Meteorology, 197, 235-243. 
Genet, H., Bréda, N., \& Dufrêne, E. (2010). Age-related variation in carbon allocation at tree and stand scales in beech (Fagus sylvatica L.) and sessile oak (Quercus petraea (Matt.) Liebl.) using a chronosequence approach. Tree Physiology, 30, 177-192.

Gerell, R. (1988). Faunal diversity and vegetation structure of some deciduous forests in South Sweden. Ecography, 11, 87-95.

Giesecke, T., Hickler, T., Kunkel, T., Sykes, M. T., \& Bradshaw, R. H. (2007). Towards an understanding of the Holocene distribution of Fagus sylvatica L. Journal of Biogeography, 34, 118-131.

Gill, R. M. A. (1992). A review of damage by mammals in north temperate forests: 1. Deer. Forestry, $65,145-169$.

Glatzel, G. (1991). The impact of historic land use and modern forestry on nutrient relations of Central European forest ecosystems. Fertilizer Research, 27, 1-8.

Gossner, M.M., Lewinsohn, T.M., Kahl, T., Grassein, F., Boch, S., Prati, D., ... \& Allan, E. (2016). Landuse intensification causes multitrophic homogenization of grassland communities. Nature, 540, 266-269.

Gossner, M. M., Simons, N.K., Achtziger, R., Blick, T., Dorow, W.H.O., Dziock, F., ... \& Weisser, W.W. (2015). A summary of eight traits of Coleoptera, Hemiptera, Orthoptera and Araneae, occurring in grasslands in Germany. Scientific Data, 2, 150013.

Greaver, T. L., Clark, C. M., Compton, J. E., Vallano, D., Talhelm, A. F., Weaver, C. P., ... \& Haeuber, R.A. (2016). Key ecological responses to nitrogen are altered by climate change. Nature Climate Change, $6,836$.

Grossiord, C., Granier, A., Ratcliffe, S., Bouriaud, O., Bruelheide, H., Checko, E., ... \& Gessler, A. (2014). Tree diversity does not always improve resistance of forest ecosystems to drought. Proceedings of the National Academy of Sciences, 111, 14812-14815

Grossman, J.J., Vanhellemont, M., Barsoum, N., Bauhus, J., Bruelheide, H., Castagneyrol, B. ... Verheyen, K. (2018). Synthesis and future research directions linking tree diversity to growth, survival, and damage in a global network of tree diversity experiments. Environmental and Experimental Botany, doi: 10.1016/j.envexpbot.2017.12.015.

Guckland, A., Jacob, M,. Flessa, H., Thomas, F.M. \& Leuschner, C. (2009) Acidity, nutrient stocks, and organic-matter content in soils of a temperate deciduous forest with different abundance of European beech (Fagus sylvatica L.). Journal of Plant Nutrition and Soil Science, 172, 500-511

Gustafsson, L., Kouki, J. \& Sverdrup-Thygeson, A. (2010). Tree retention as a conservation measure in clear-cut forests of Northern Europe: a review of ecological consequences. Scandinavian Journal of Forest Research, 25, 295-308. 
Gustafsson, L., Baker, S.C., Bauhus, J., Beese, W.J., Brodie, A., Kouki, J., ... \& Franklin, J. F. (2012). Retention Forestry to Maintain Multifunctional Forests: A World Perspective. BioScience 62:633645.

Hannon, G. E., Niklasson, M., Brunet, J., Eliasson, P., \& Lindbladh, M. (2010). How long has the "hotspot" been "hot"? Past stand-scale structures at Siggaboda nature reserve in southern Sweden. Biodiversity and Conservation, 19, 2167-2187.

Hartmann, H., Adams, H. D., Anderegg, W. R., Jansen, S., \& Zeppel, M. J. (2015). Research frontiers in drought-induced tree mortality: crossing scales and disciplines. New Phytologist, 20, 965-969.

Hartmann H., Schuldt, B., Sanders, T.G.M., Macinnis-Ng, C. Boehmer, H.J., Allen, C.D., ... \& Anderegg, W.R.L. (2018). Monitoring global tree mortality patterns and trends. Report from the VW symposium 'Crossing scales and disciplines to identify global trends of tree mortality as indicators of forest health'. New Phytologist, 217, 984-987.

Heer, K., Behringer, D., Piermattei, A., Bässler, C., Brandl, R., Fady, B., Jehl, H., Liepelt, S., Lorch, S., Piotti, A., Vendramin, G.G., Weller, M., Ziegenhagen, B., Büntgen, U. \& Opgenoorth, L. (2018). Linking dendroecology and association genetics in natural populations: Stress response archived in tree rings associate with SNP genotypes in silver fir (Abies alba Mill.). Molecular Ecology, 27, 14281438.

Hermy, M., \& Verheyen, K. (2007). Legacies of the past in the present-day forest biodiversity: A review of past land-use effects on forest plant species composition and diversity. Ecological Research, 22, 361-371.

Hess, C., Niemeyer, T., Fichtner, A., Jansen, K., Kunz, M., Maneke, M., ... \& Härdtle, W. (2018). Anthropogenic nitrogen deposition alters growth responses of European beech (Fagus sylvativa L.) to climate change. Environmental Pollution, 233, 92-98.

Holzwarth, F., Kahl, A., Bauhus, J., \& Wirth, C. (2013). Many ways to die-partitioning tree mortality dynamics in a near-natural mixed deciduous forest. Journal of Ecology, 101(1), 220-230.

Homburg, K., Schuldt, A., Drees, C., \& Assmann, T. (2013). Broad-scale geographic patterns in body size and hind wing development of western Palaearctic carabid beetles (Coleoptera: Carabidae). Ecography, 36, 166-177.

Hooper, D.U., Adair, E.C., Cardinale, B.J., Byrnes, J.E.K., Hungate, B.A., Matulich, K.L., Gonzalez, A., Duffy, J.E., Gamfeldt, L., \& O'Connor, M.I. (2012). A global synthesis reveals biodiversity loss as a major driver of ecosystem change. Nature, 486, 105-108.

Hughes, A., Inouye, B.D., Johnson, M.T., Underwood, N. \& Vellend, M. (2008). Ecological consequences of genetic diversity. Ecology Letters, 11, 609-623.

Hulshof, C. M., Violle, C., Spasojevic, M. J., McGill, B., Damschen, E., Harrison, S., \& Enquist, B. J. 2013. Intra-specific and inter-specific variation in specific leaf area reveal the importance of abiotic and 
biotic drivers of species diversity across elevation and latitude. Journal of Vegetation Science, 24, 921-931.

Humphrey, J.W., Watts, K., Fuentes-Montemayor, E., Macgregor, N.A., Peace, A.J. \& Park, K.J. (2015). What can studies of woodland fragmentation and creation tell us about ecological networks? A literature review and synthesis. Landscape Ecology, 30, 21-50.

Hutchinson, G.E. (1959). Homage to Santa Rosalia or Why are there so many kings of animals? American Naturalist, 93, 145-159.

Huxel, G.R. \& Hastings, A. (1999). Habitat Loss, Fragmentation, and Restoration. Restoration Ecology, 7, 309-315.

Jacob, M., Leuschner, C. \& Thomas F.M. (2010) Productivity of temperate broad-leaved forest stands differing in tree species diversity. Annals of Forest Science, 67, 503p1-503p9.

Jacob, M., Viedenz, K., Polle, A. \& Thomas, F.M. (2010) Leaf litter decomposition in temperate deciduous forest stands with a decreasing fraction of beech (Fagus sylvatica). Oecologia, 164, 10831094.

Jactel, H., Brockerhoff, E., \& Duelli P. (2005). A test of the biodiversity-stability theory: Meta-analysis of tree species diversity effects on insect pest infestations, and re-examination of responsible factors. In M. Scherer-Lorenzen, C. Körner, \& E.-D. Schulze (Eds.), Forest Diversity and Function: Temperate and Boreal Systems (pp.235-262). Berlin, Heidelberg: Springer.

Jaloviar, P., Saniga, M., Kucbel, S., Pittner, J., Vencurik, J., \& Dovciak, M. (2017). Seven decades of change in a European old-growth forest following a stand-replacing wind disturbance: A long-term case study. Forest Ecology and Management, 399, 197-205.

Janda, P., Trotsiuk, V., Mikoláš, M., Bače, R., Nagel, T. A., Seidl, R., ... \& Svoboda, M. (2017). The historical disturbance regime of mountain Norway spruce forests in the Western Carpathians and its influence on current forest structure and composition. Forest Ecology and Management, 388, $67-78$

Janssen, P., Fuhr, M., Cateau, E., Nusillard, B., \& Bouget, C. (2017). Forest continuity acts congruently with stand maturity in structuring the functional composition of saproxylic beetles. Biological Conservation, 205, 1-10.

Jiménez-Alfaro, B., Girardello, M., Chytrý, M. Svenning, J.-C., Willner, W., Géout, J.-C., ... \& Wohlgemuth, T. (2018) History and environment shape species pools and community diversity in European beech forests. Nature Ecology \& Evolution, 2, 483-490.

Johann, F., \& Schaich, H. (2016). Land ownership affects diversity and abundance of tree microhabitats in deciduous temperate forests. Forest Ecology and Management, 380, 70-81. 
Johnstone, J.F., Allen, C.D., Franklin, J.F., Frelich, L.E., Harvey, B.J., Higuera, P.E., ... \& Turner, M.G. (2016). Changing disturbance regimes, ecological memory, and forest resilience. Frontiers in Ecology and the Environment, 14, 369-378.

Joosten, H., \& Tanneberger, F. (2017). Examples of peat-consuming use. In: H. Joosten, F. Tanneberger \& A. Moen (Eds.), Mires and Peatlands of Europe: Status, Distribution and Conservation (pp. 178179). Stuttgart: Schweizerbart Science Publishers

Juchheim, J., Ammer, C., Schall, P., \& Seidel, D. (2017). Canopy space filling rather than conventional measures of structural diversity explains productivity of beech stands. Forest Ecology and Management 395, 19-26.

Jucker, T., Avăcăriței, D., Bărnoaiea, I., Duduman, G., Bouriaud, O., \& Coomes, D.A. (2016). Climate modulates the effects of tree diversity on forest productivity. Journal of Ecology, 104, 388-398.

Kaplan, J. O., Krumhardt, K. M., \& Zimmermann, N. (2009). The prehistoric and preindustrial deforestation of Europe. Quaternary Science Reviews, 28, 3016-3034.

Karnosky, D. F. (1979). Dutch elm disease: a review of the history, environmental implications, control, and research needs. Environmental Conservation, 6, 311-322.

Karr, J.R. \& Roth, R.R. (1971). Vegetation Structure and Avian Diversity in Several New World Areas. The American Naturalist, 105, 423-435.

Kattge, J., Diaz, S., Lavorel, S., Prentice, I. C., Leadley, P., Bönisch, G., ... Wirth, C. (2011). TRY - a global database of plant traits. Global Change Biology, 17, 2905-2935.

Keddy P.A. (2017): Plant Ecology. Organs Processes, Consequences. Cambridge University Press, second edition.

Keenan, R.J. (2015). Climate change impacts and adaptation in forest management: a review. Annals of Forest Science, 72, 145-167.

Kirby, K. J., \& Watkins, C. (1998). Ecological history of European forests. CAB International.

Klein, T., Siegwolf, R.T.W. \& Körner, C. (2016) Belowground carbon trade among tall trees in a temperate forest. Science, 352, 342-344.

Knoke, T., Ammer, C., Stimm, B., \& Mosandl, R. (2008). Admixing broadleaved to coniferous tree species: a review on yield, ecological stability and economics. European Journal of Forest Research, $127,89-101$.

Komonen, A. \& Müller, J. (2018). Dispersal ecology of deadwood organisms and connectivity conservation. Conservation Biology, doi: 10.1111/cobi.13087

Kremen, C. (2005). Managing ecosystem services: what do we need to know about their ecology. Ecology Letters, 8, 468-479.

Kraus, D., \& Krumm, F. (Eds.) (2013). Integrative approaches as an opportunity for the conservation of forest biodiversity. Joensuu: European Forest Institute. 
Künkler, N., Brandl, R. \& Brändle, M. (2013). Changes in clonal poplar leaf chemistry caused by stem galls alter herbivory and leaf litter decomposition. PLoS ONE, 8, e79994.

Kulakowski, D., Seidl, R., Holeksa, J., Kuuluvainen, T., Nagel, T. A., Panayotov, M., ... \& Wohlgemuth, T. (2017). A walk on the wild side: disturbance dynamics and the conservation and management of European mountain forest ecosystems. Forest Ecology and Management, 388, 120-131.

Kupferschmid, A. D., \& Bugmann, H. (2005). Effect of microsites, logs and ungulate browsing on Picea abies regeneration in a mountain forest. Forest Ecology and Management, 205, 251-265.

Lachat, T., \& Bütler, R. (2009). Identifying conservation and restoration priorities for saproxylic and oldgrowth forest species: a case study in Switzerland. Environmental Management, 44, 105-118.

Lafond, V., Cordonnier, T., Mao, Z., \& Courbaud, B. (2017). Trade-offs and synergies between ecosystem services in uneven-aged mountain forests: evidences using Pareto fronts. European journal of forest research, 136, 997-1012.

Langner, A., Irauschek, F., Perez, S., Pardos, M., Zlatanov, T., Öhman, K., ... \& Lexer, M. J. (2017). Valuebased ecosystem service trade-offs in multi-objective management in European mountain forests. Ecosystem services, 26, 245-257.

Larrieu, L., Cabanettes, A., Gonin, P., Lachat, T., Paillet, Y., Winter, S., ... \& Deconchat M. 2014. Deadwood and tree microhabitat dynamics in unharvested temperate mountain mixed forests: A life-cycle approach to biodiversity monitoring. Forest Ecology Management, 334, 163-173.

Laudon, H., Kuglerová, L., Sponseller, R. A., Futter, M., Nordin, A., Bishop, K., ... \& Ågren, A. M. (2016). The role of biogeochemical hotspots, landscape heterogeneity, and hydrological connectivity for minimizing forestry effects on water quality. Ambio, 45, 152-162.

Lavorel, S., \& Garnier, É. (2002). Predicting changes in community composition and ecosystem functioning from plant traits: revisiting the Holy Grail. Functional Ecology, 16, 545-556.

Lavorel, S., Storkey, J., Bardgett, R. D., de Bello, F., Berg, M. P., Le Roux, X., ... \& Harrington, R. (2013). A novel framework for linking functional diversity of plants with other trophic levels for the quantification of ecosystem services. Journal of Vegetation Science, 24, 942-948.

Lei, P., Scherer-Lorenzen, M., \& Bauhus, J. (2012). Belowground facilitation and competition in young tree species mixtures. Forest Ecology and Management, 265, 191-200.

Lepš, J., de Bello, F., Šmilauer, P., \& Doležal, J. ( 2011). Community trait response to environment: Disentangling species turnover vs intraspecific trait variability effects. Ecography, 34, 856-863.

Leuschner, C., \& Ellenberg, H. (2017). Ecology of Central European Forests. Berlin and Heidelberg: Springer.

Leuzinger, S., Luo, Y., Beier, C., Dieleman, W., Vicca, S., \& Koerner, C. (2011). Do global change experiments overestimate impacts on terrestrial ecosystems? Trends in Ecology and Evolution, 26, $236-241$. 
Liang, J., Crowther, T.W., Picard, N., Wiser, S., Zhou, M., Alberti, G., ... \& Reich, P.B. (2016). Positive biodiversity-productivity relationship predominant in global forests. Science, 354, aaf8957.

Lindbladh, M., Lindström, A., Hedwall, P.-O., \& Felton, A. (2017). Avian diversity in Norway spruce production forests? How variation in structure and composition reveals pathways for improving habitat quality. Forest Ecology and Management, 397, 48-56.

Lindenmayer, D. B., \& Franklin, J. F. (1997). Managing Stand Structure as Part of Ecologically Sustainable Forest Management in Australian Mountain Ash Forests. Conservation Biology 11, 1053-1068.

Lindenmayer, D.B., Likensa, G.E., Krebs, C.J., \& Hobbs, R.J. (2010). Improved probability of detection of ecological "surprises". Proceedings of the National Academy of Sciences of the United States of America, 107, 21957-21962.

Lindner, M., Maroschek, M., Netherer, S., Kremer, A., Barbati, A., Garcia-Gonzalo, J., ... \& Marchetti, M. (2010). Climate change impacts, adaptive capacity, and vulnerability of European forest ecosystems. Forest Ecology and Management 259, 698-709.

Liu, J., Dietz, T., Carpenter, S. R., Alberti, M., Folke, C., Moran, E., ... \& Taylor, W.W. (2007). Complexity of coupled human and natural systems. Science, 317(5844), 1513-1516.

Loreau, M. (2000). Biodiversity and ecosystem functioning: recent theoretical advances. Oikos 91, 317.

Luyssaert, S., Ciais, P., Piao, S. L., Schulze, E. D., Jung, M., Zaehle, S., ... \& Abril, G. (2010). The European carbon balance. Part 3: forests. Global Change Biology, 16, 1429-1450

MacArthur, R.H. \& MacArthur, J.W. (1961). On bird species diversity. Ecology, 42, 594-598.

Malyshev, A. V., Henry, H. A., Bolte, A., Khan, M. A. A., \& Kreyling, J. (2018). Temporal photoperiod sensitivity and forcing requirements for budburst in temperate tree seedlings. Agricultural and Forest Meteorology, 248, 82-90.

Mann, M.E., Rahmstorf, S., Kornhuber, K., Steinman, B.A., Miller, S.K., \& Coumou, D. (2017). Influence of anthropogenic climate change on planetary wave resonance and extreme weather events. Scientific Reports, 7, 45242.

Matyssek, R., Wieser, G., Patzner, K., Blaschke, H. \& Häberle, K.-H. (2009). Transpiration of forest trees and stands at different altitude: consistencies rather than contrasts? European Journal of Forest Research, 128, 579-596.

Mausolf, K., Härdtle, W., Jansen, K., Delory, B.M., Hertel, D., Leuschner, C., Temperton, V.M., von Oheimb, G. \& Fichtner, A. (2018). Legacy effects of land-use modulate tree growth responses to climate extremes. Oecologia, 187, 825-837.

McCarthy, M.C., \& Enquist, B.J. (2007). Consistency between an allometric approach and optimal partitioning theory in global patterns of plant biomass allocation. Functional Ecology, 21, 713-720. 
McKinney, M.L. \& Lockwood, J.L. (1999). Biotic homogenization: a few winners replacing many losers in the next mass extinction. Trends in Ecology \& Evolution, 14, 450-453.

McLaughlin, B. C., Ackerly, D. D., Klos, P. Z., Natali, J., Dawson, T. E., \& Thompson, S. E. (2017). Hydrologic refugia, plants, and climate change. Global Change Biology, 23, 2941-2961.

Meier, I. C., \& Leuschner, C. (2008). Genotypic variation and phenotypic plasticity in the drought response of fine roots of European beech. Tree Physiology, 28, 297-309.

Meinzer, F.C., Warren, J.M., \& Brooks, J.R. (2007). Species-specific partitioning of soil water resources in an old-growth Douglas-fir-western hemlock forest. Tree Physiology, 27, 871-880.

Meißner, M., Köhler, M., Schwendenmann, L. \& Hölscher, D. (2012). Partitioning of soil water among canopy trees during a soil desiccation period in a temperate mixed forest. Biogeosciences, 9, 34653474.

Menzel, A., \& Fabian, P. (1999). Growing season extended in Europe. Nature, 397(6721), 659.

Messier, C., Puettmann, K., Chazdon, R., Andersson, K. P., Angers, V. A., Brotons, L., ... \& Levin, S. A. (2015). From management to stewardship: viewing forests as complex adaptive systems in an uncertain world. Conservation Letters, 8, 368-377.

Millennium Ecosystem Assessment (2005). Ecosystems and human well-being: synthesis. Island Press, Washington, D.C., USA.

Mikoláš, M., Svitok, M., Bollmann, K., Reif, J., Bače, R., Janda, P., ... \& Svoboda, M. (2017). Mixedseverity natural disturbances promote the occurrence of an endangered umbrella species in primary forests. Forest Ecology and Management, 405, 210-218.

Mölder, A. (2016). Small forest parcels, management diversity and valuable coppice habitats: An 18th century political compromise in the Osnabrück region (NW Germany) and its long-lasting legacy. iForest, 9, 518-528.

Mori, A. S., Lertzman, K. P., Gustafsson, L., \& Cadotte, M. (2017). Biodiversity and ecosystem services in forest ecosystems: A research agenda for applied forest ecology. Journal of Applied Ecology, 54, $12-27$.

Motta, R. (1996). Impact of wild ungulates on forest regeneration and tree composition of mountain forests in the Western Italian Alps. Forest Ecology and Management, 88, 93-98.

Motta, R., \& Lingua, E. (2005). Human impact on size, age, and spatial structure in a mixed European larch and Swiss stone pine forest in the Western Italian Alps. Canadian Journal of Forest Research, $35,1809-1820$.

Müller, J., Bae, S., Röder, J., Chao, A., \& Didham, R. K. (2014). Airborne LiDAR reveals context dependence in the effects of canopy architecture on arthropod diversity. Forest Ecology and Management, 312, 129-137. 
Müller, J., \& Bütler, R. (2010). A review of habitat thresholds for dead wood: a baseline for management recommendations in European forests. European Journal of Forest Research, 129, 981-992.

Müller, J., Hothorn, T., \& Pretzsch, H. (2007). Long-term effects of logging intensity on structures, birds, saproxylic beetles and wood-inhabiting fungi in stands of European beech Fagus sylvatica L. Forest Ecology and Management, 242, 297-305.

Müller, J. \& Opgenoorth, L. (2014). On the gap between science and conservation implementation - A national park perspective. Basic and Applied Ecology, 15, 373-378.

Nadrowski, K., Wirth, C., Scherer-Lorenzen, M. (2010). Is forest diversity driving ecosystem function and service? Current Opinion in Environmental Sustainability, 2, 75-79.

Nagel, T. A., \& Diaci, J. (2006). Intermediate wind disturbance in an old-growth beech-fir forest in southeastern Slovenia. Canadian Journal of Forest Research, 36(3), 629-638.

Nagel, T. A., Svoboda, M., \& Kobal, M. (2014). Disturbance, life history traits, and dynamics in an oldgrowth forest landscape of southeastern Europe. Ecological Applications, 24, 663-679.

Neumann, M., Mues, V., Moreno, A., Hasenauer, H., \& Seidl, R. (2017). Climate variability drives recent tree mortality in Europe. Global Change biology, 23, 4788-4797.

Neumann, M., \& Starlinger, F. (2001). The significance of different indices for stand structure and diversity in forests. Forest ecology and Management, 145, 91-106.

Niklaus, P.A., Baruffol, M., He, J.-S., Ma, K., \& Schmid, B. (2017). Can niche plasticity promote biodiversity-productivity relationships through increased complementarity? Ecology, 98, 11041116.

Nordén, B., Dahlberg, A., Brandrud, T. E., Fritz, Ö., Ejrnaes, R., \& Ovaskainen, O. (2014). Effects of ecological continuity on species richness and composition in forests and woodlands: a review. Ecoscience, 21, 34-45.

Nuzzo, V. A., Maerz, J. C., \& Blossey, B. (2009). Earthworm invasion as the driving force behind plant invasion and community change in northeastern North American forests. Conservation Biology, 23, 966-974

O'Brien, M. J., Engelbrecht, B. M., Joswig, J., Pereyra, G., Schuldt, B., Jansen, S., ... \& Macinnis-Ng, C. (2017). A synthesis of tree functional traits related to drought-induced mortality in forests across climatic-zones. Journal of Applied Ecology, 54, 1669-1686.

Oheimb, G. von, Härdtle, W., Naumann, P. S., Westphal, C., Assmann, T., \& Meyer, H. (2008). Longterm effects of historical heathland farming on soil properties of forest ecosystems. Forest Ecology and Management, 255, 1984-1993. 
Ohlson, M., Söderström, L., Hörnberg, G., Zackrisson, O. \& Hermansson, J. (1997). Habitat qualities versus long-term continuity as determinants of biodiversity in boreal old-growth swamp forests. Biological Conservation, 81, 221-231.

Ogilvie, B.W. (2008). The science of describing: Natural history in Renaissance Europe. Chicago: University of Chicago Press.

Paillet, Y., Berges, L., Hjältén, J., Odor, P., Avon, C., Bernhardt-Römermann, M., ... \& Virtanen, R (2010). Biodiversity differences between managed and unmanaged forests: meta-analysis of species richness in Europe. Conservation Biology, 24, 101-112.

Paquette, A., \& Messier, C. (2011). The effect of biodiversity on tree productivity: from temperate to boreal forests. Global Ecology and Biogeography, 20, 170-180.

Paquette, A., Vayreda, J., Coll, L., Messier, C., \& Retana, J. (2017): Climate change could negate positive tree diversity effects on forest productivity: A study across five climate types in Spain and Canada. Ecosystems, doi.org/10.1007/s10021-017-0196-y.

Parviainen, J. (2005). Virgin and natural forests in the temperate zone of Europe. Forest Snow and Landscape Research, 79, 9-18.

Parviainen, J., Bücking W., Vandekerkhove, K., Schuck, A., \& Päivinen, R. (2000): Strict forest reserves in Europe: Efforts to enhance biodiversity and research on forests left for free development in Europe (EU-COST-Action E4). Forestry, 73, 107-118.

Pautasso, M., Aas, G., Queloz, V., \& Holdenrieder, O. (2013). European ash (Fraxinus excelsior) diebacka conservation biology challenge. Biological Conservation, 158, 37-49.

Pedro, M. S., Rammer, W., \& Seidl, R. (2015). Tree species diversity mitigates disturbance impacts on the forest carbon cycle. Oecologia, 177, 619-630.

Pellerin, M., Saïd, S., Richard, E., Hamann, J. L., Dubois-Coli, C., \& Hum, P. (2010). Impact of deer on temperate forest vegetation and woody debris as protection of forest regeneration against browsing. Forest Ecology and Management, 260, 429-437.

Perring, M.P., De Frenne, P., Baeten, L., Maes, S.L., Depauw, L., Blondeel, H., ... \& Verheyen, K. (2016) Global environmental change effects on ecosystems: the importance of land-use legacies. Global Change Biology, 22, 1361-1371.

Petriţan, A. M., Bouriaud, O., Frank, D. C., \& Petriţan, I. C. (2017). Dendroecological reconstruction of disturbance history of an old-growth mixed sessile oak-beech forest. Journal of Vegetation Science, $28,117-127$.

Pötzelsberger, E., \& Hasenauer, H. (2015). Forest-water dynamics within a mountainous catchment in Austria. Natural Hazards, 77, 625-644.

Pommerening, A. (2002). Approaches to quantifying forest structures. Forestry 75,305-324. 
Prescott, C.E. (2010). Litter decomposition: what controls it and how can we alter it to sequester more carbon in forest soils? Biogeochemistry, 101, 133-149.

Pretzsch, H., Biber, P., Schütze, G., Uhl, E., \& Rötzer, T. (2014). Forest stand growth dynamics in Central Europe have accelerated since 1870. Nature Communications, 5, 4967.

Pretzsch, H., Forrester, D. I., \& Bauhus, J. (Eds.). (2017). Mixed-species forests: Ecology and management. Berlin: Springer.

Pretzsch, H., Schütze, G., \& Uhl, E. (2013). Resistance of European tree species to drought stress in mixed versus pure forests: evidence of stress release by inter-specific facilitation. Plant Biology, 15, 483-495.

Prietzel, J., \& Ammer, C. (2008). Montane Bergmischwälder der Bayerischen Kalkalpen: Reduktion der Schalenwilddichte steigert nicht nur den Verjüngungserfolg, sondern auch die Bodenfruchtbarkeit. Allgemeine Forst-und Jagdzeitung, 179, 104-112.

Radkau, J. (2012). Wood: A History. Cambridge: Polity Press.

Rahmstorf, S., \& Coumou, D. (2011). Increase of extreme events in a warming world. Proceedings of the National Academy of Sciences 108, 17905-17909.

Rammer, W., Brauner, M., Ruprecht, H., \& Lexer, M. J. (2015). Evaluating the effects of forest management on rockfall protection and timber production at slope scale. Scandinavian Journal of Forest Research, 30, 719-731.

Ratcliffe, S., Wirth, C., Jucker, T., der Plas, F., Scherer-Lorenzen, M., Verheyen, K., ... \& Baeten, L. (2017). Biodiversity and ecosystem functioning relations in European forests depend on environmental context. Ecology Letters, 20, 1414-1426.

Reich, P.B. (2012). Key canopy traits drive forest productivity. Proceedings of the Royal Society of London B: Biological Sciences, 279, 2128-2134.

Reimoser, F. (2003). Steering the impacts of ungulates on temperate forests. Journal for Nature Conservation, 10, 243-252.

Reyer, C.P.O., Brouwers, N., Rammig, A., Brook, B.W., Epila, J., Grant, R.F., ... \& Villela , D.M. (2015). Forest resilience and tipping points at different spatio-temporal scales: approaches and challenges. Journal of Ecology, 103, 5-15.

Rooney, T. P. (2001). Deer impacts on forest ecosystems: a North American perspective. Forestry, 74, 201-208.

Rose, L., Leuschner, C., Köckemann, B. and Buschmann, H. (2009). Are marginal beech (Fagus sylvatica L.) provenances a source for drought tolerant ecotypes? European Journal of Forest Research, 128, 335-343.

Roxburgh, S.H., Shea, K., \& Wilson, J.B. (2004). The intermediate disturbance hypothesis: patch dynamics and mechanisms of species coexistence. Ecology, 85, 359-371. 
Ruiz-Benito, P., Ratcliffe, S., Jump, A.S., Gómez-Aparicio, L., Madrigal-González, J., Wirth, C.,... \& Zavala, M.A. (2017). Functional diversity underlies demographic responses to environmental variation in European forests. Global Ecology and Biogeography, 26, 128-141.

Ruiz-Benito, P., Madrigal-González, J., Ratcliffe, S., Coomes, D.A., Kändler, G., Lehtonen, A., ... \& Zavala, M.A. (2014). Stand structure and recent climate change constrain stand basal area change in European forests: a comparison across boreal, temperate, and Mediterranean biomes. Ecosystems, $17,1439-1454$.

Sanders, T., Michel, A., \& Ferretti, M. (2016). 30 years of monitoring the effects of long-range transboundary air pollution on forests in Europe and beyond. UNECE/ICP Forests, Eberswalde, 67 p.

Sarkar, N., Schmid-Siegert, E., Iseli, C., Calderon, S., Gouhier-Darimont, C., Chrast, J., ... \& Reymond, P. (2017). Low rate of somatic mutations in a long-lived oak tree. bioRxiv, 149203.

Sala, O. E., Chapin, F. S., Armesto, J. J., Berlow, E., Bloomfield, J., Dirzo, R., \& Kinzig, A. (2000). Global biodiversity scenarios for the year 2100. Science, 287, 1770-1774.

Schall, P., \& Ammer, C. (2013). How to quantify forest management intensity in Central European Forests. European Journal of Forest Research, 132, 379-396.

Schall, P., Gossner, M.M., Heinrichs, S., Fischer, M., Boch, S., Prati, D., ... \& Ammer, C. (2018). The impact of even-aged and uneven-aged forest management on regional biodiversity of multiple taxa in European beech forests. Journal of Applied Ecology, 55, 267-278.

Schall, P., Schulze, E.-D., Fischer, M., Ayasse, M., \& Ammer, C. (2018). Relations between forest management, stand structure and productivity across different types of Central European forests. Basic and Applied Ecology. doi.org/10.1016/i.baae.2018.02.007

Scheffer, M., Carpenter, S., Foley, J.A., Folke, C., \& Walker, B. 2001. Catastrophic shifts in ecosystems. Nature, 413, 591.

Scherer-Lorenzen, M. (2014). The functional role of biodiversity in the context of global change. In: D. Burslem, D. Coomes, \& W. Simonson (Eds.) Forests and Global Change (pp. 195-238). Cambridge: Cambridge University Press.

Scherer-Lorenzen, M., Körner, C., \& Schulze, E.-D. (Eds.) (2005). Forest diversity and function. Temperate and boreal systems. Ecological Studies 176. Berlin, Heidelberg, New York: Springer.

Schröter, D., Cramer, W., Leemans, R., Prentice, I. C., Araújo, M. B., Arnell, N. W., ... \& Zierl, B. (2005). Ecosystem service supply and vulnerability to global change in Europe. Science, 310, 1333-1337.

Schuldt, B., Knutzen, F., Delzon, S., Jansen, S., Muller-Haubold, H., Burlett, ... \& Leuschner, C. (2016). How adaptable is the hydraulic system of European beech in the face of climate change-related precipitation reduction? New Phytologist, 210, 443-458. 
Schulze, E.-D. (2000) The Carbon and Nitrogen Cycle of Forest Ecosystems. Springer, Ecological Studies 142.

Schulze, E.-D., Aas, G., Grimm, G.W., Gossner, M.M., Walentowski, H., Ammer, C., ... \& von Gadow, K. (2016). A review on plant-diversity and forest Management of European beech forests. European Journal of Forest Research, 135, 51-67.

Schurman, J. S., Trotsiuk, V., Bače, R., Čada, V., Fraver, S., Janda, P., ... \& Seidl, R. (2018). Large-scale disturbance legacies and the climate sensitivity of primary Picea abies forests. Global Change Biology, doi.org/10.1111/gcb.14041

Schweingruber, F.H., \& Wirth, C. (2009). Old trees and the meaning of 'old'. In: C. Wirth, G. Gleixner, \& M. Heimann (Eds.), Old-growth forests - function, fate and value (pp. 35-54). Berlin: Springer.

Seibold, S., Bässler, C., Brandl, R., Büche, B., Szallies, A., Thorn, S., .... \& Müller, J. (2016): Microclimate and habitat heterogeneity as the major drivers of beetle diversity in dead wood. Journal of Applied Ecology, 53, 934-943.

Seibold, S., Bässler, C., Brandl, R., Fahrig, L., Förster, B., Heurich, M., ... \& Müller, J. (2017). An experimental test of the habitat-amount hypothesis for saproxylic beetles in a forested region. Ecology, 98, 1613-1622.

Seidel, D. (2018). A holistic approach to determine tree structural complexity based on laser scanning data and fractal analysis. Ecology and Evolution, 8, 128-134

Seidl, R., Klonner, G., Rammer, W., Essl, F., Moreno, A., Neumann, M., \& Dullinger, S. (2018). Invasive alien pests threaten the carbon stored in Europe's forests. Nature Communications, 9, 1626.

Seidl, R., Schelhaas, M. J., Rammer, W., \& Verkerk, P. J. (2014). Increasing forest disturbances in Europe and their impact on carbon storage. Nature Climate Change, 4, 806.

Seidl, R., Spies, T. A., Rammer, W., Steel, E. A., Pabst, R. J., \& Olsen, K. (2012). Multi-scale drivers of spatial variation in old-growth forest carbon density disentangled with Lidar and an individualbased landscape model. Ecosystems, 15, 1321-1335.

Seidl, R., Thom, D., Kautz, M., Martin-Benito, D., Peltoniemi, M., Vacchiano, G., ... \& Reyer, P.O. (2017). Forest disturbances under climate change. Nature Climate Change, 7, 395-402.

Seidl, R., Albrich, K., Thom, D., \& Rammer, W. (2018). Harnessing landscape heterogeneity for managing future disturbance risks in forest ecosystems. Journal of Environmental Management, 209, 46-56.

Sevanto, S., McDowell, N. G., Dickman, L. T., Pangle, R., \& Pockman, W. T. (2014). How do trees die? A test of the hydraulic failure and carbon starvation hypotheses. Plant, Cell \& Environment, 37, 153161. 
Seymour, R. S., White, A. S., \& deMaynadier, P.G. (2002). Natural disturbance regimes in northeastern North America-evaluating silvicultural systems using natural scales and frequencies. Forest Ecology and Management, 155, 357-367.

Shipley, B., \& Meziane, D. (2002). The balanced-growth hypothesis and the allometry of leaf and roots biomass allocation. Functional Ecology, 16, 326-331.

Silvertown, J., Araya, Y., Gowing, D. (2015). Hydrological niches in terrestrial plant communities: a review. Journal of Ecology, 103, 93-108.

Simard, M., Pinto, N., Fisher, J. B., \& Baccini, A. (2011): Mapping forest canopy height globally with spaceborne lidar. Journal of Geophysical Research, 116 (G4), 248.

Simberloff, D. (1999). The role of science in the preservation of forest biodiversity. Forest Ecology and Management, 115, 101-111.

Sing, L., Metzger, M.J., Paterson, J.S., \& Ray, D. (2018). A review of the effects of forest management intensity on ecosystem services for northern European temperate forests with a focus on the UK. Forestry, 91, 151-164.

Soliveres, S., Van Der Plas, F., Manning, P., Prati, D., Gossner, M. M., Renner, S. C., ... \& Allan, E. (2016). Biodiversity at multiple trophic levels is needed for ecosystem multifunctionality. Nature, 536(7617), 456.

Spellmann, H., Weller, A., Brang, P., Michiels, H.-G., \& Bolte, A. (2015). Douglasie. In T. Vor, H. Spellmann, A. Bolte, \& C. Ammer (Eds.) Potenziale und Risiken eingeführter Baumarten. Baumartenportraits mit naturschutzfachlicher Bewertung (pp. 142-165). Göttingen: Universitätsverlag Göttingen.

Srivastava, D. S., \& Lawton, J. H. (1998). Why more productive sites have more species: an experimental test of theory using tree-hole communities. The American Naturalist, 152, 510-529.

Stephenson, N. L., Das, A. J., Condit, R., Russo, S. E., Baker, P. J., Beckman, N. G., ... \& Alvarez, E. (2014). Rate of tree carbon accumulation increases continuously with tree size. Nature, 507(7490), 90.

Stoffels, J., Hill, J., Sachtleber, T., Mader, S., Buddenbaum, H., Stern, O.,... \& Ontrup, G. (2015). Satellitebased derivation of high-resolution forest information layers for operational forest management. Forests, 6, 1982-2013.

Stojnić, S., Suchocka, M., Benito-Garzón, M., Torres-Ruiz, J. M., Cochard, H., Bolte, A., ... \& Delzon, S. (2018). Variation in xylem vulnerability to embolism in European beech from geographically marginal populations. Tree physiology, 38, 173-185.

Strätz, C., Wagner, S., \& Müller, J. (2009). Räumliche Effekte von Totholzstrukturen bei Landschnecken (Mollusca: Gastropoda). Forst und Holz, 64, 22-27. 
Suseela, V., \& Tharayil, N. (2018). Decoupling the direct and indirect effects of climate on plant litter decomposition: Accounting for stress-induced modifications in plant chemistry. Global Change Biology, 24, 1428-1451.

Sutherland, W.J., Freckleton, R.P., Godfray, H.C.J., Beissinger, S.R., Benton, T., Cameron, D.D., ... \& Wiegand, T. (2013) Identification of 100 fundamental ecological questions. Journal of Ecology, 101, 58-67.

Svoboda, M., Janda, P., Bače, R., Fraver, S., Nagel, T. A., Rejzek, J., ... \& Lehejček, J. (2014). Landscapelevel variability in historical disturbance in primary Picea abies mountain forests of the $\mathrm{E}$ astern Carpathians, Romania. Journal of Vegetation Science, 25, 386-401.

Szabó, P., \& Hédl, R. (2011). Advancing the integration of history and ecology for conservation. Conservation Biology, 25, 680-687.

Thomas, F.M., Bögelein, R., \& Werner, W. (2015). Interaction between Douglas fir and European beech - investigations in pure and mixed stands. Forstarchiv, 86, 83-91.

Thomas, H. (2013). Senescence, ageing and death of the whole plant. New Phytologist, 197, 696-711.

Thom, D., Rammer, W., Dirnböck, T., Müller, J., Kobler, J., Katzensteiner, K., ... \& Seidl, R. (2017). The impacts of climate change and disturbance on spatio-temporal trajectories of biodiversity in a temperate forest landscape. Journal of Applied Ecology, 54, 28-38.

Thom, D., \& Seidl, R. (2016) Natural disturbance impacts on ecosystem services and biodiversity in temperate and boreal forests. Biological Reviews, 91, 760-781

Trumbore, S., Brando, P., \& Hartmann, H. (2015). Forest health and global change. Science, 349(6250), 814-818.

Turner, D. P., Ollinger, S. V., \& Kimball, J. S. (2004). Integrating remote sensing and ecosystem process models for landscape-to regional-scale analysis of the carbon cycle. AIBS Bulletin, 54, 573-584.

Turner, M.G. (2010). Disturbance and landscape dynamics in a changing world. Ecology, 91, 2833-2849. Ulyshen, M.D. (2015). Insect-mediated nitrogen dynamics in decomposing wood. Ecological Entomology., 40, 97-112.

Ulyshen, M.D. (2016). Wood decomposition as influenced by invertebrates. Biological Reviews, 91, 7085.

van der Plas, F., Manning, P., Soliveres, S., Allan, E., Scherer-Lorenzen, M., Verheyen, K., ... \& Fischer, M. (2016) Biotic homogenization can decrease landscape-scale forest multifunctionality. Proceedings of the National Academy of Sciences, 113, 3557-3562.

van der Plas, F., Ratcliffe, S., Ruiz-Benito, P., Scherer-Lorenzen, M., Verheyen, K., Wirth, C., ... \& Allan, E. (2018). Continental mapping of forest ecosystem functions reveals a high but unrealised potential for forest multifunctionality. Ecology Letters, 21, 31-42. 
van Nes, E.H., Arani, B.M.S., Staal, A., van der Bolt, B., Flores, B.M., Bathiany, S., \&Scheffer, M. 2016. What do you mean, 'tipping point'? Trends in Ecology \& Evolution. 31: 902-904

Violle, C., Navas, M.-L., Vile, D., Kazakou, E., Fortunel, C., Hummel, I., \& Garnier, E. (2007). Let the concept of trait be functional! Oikos, 116, 882-892.

Vuidot, A., Paillet, Y., Archaux, F., \& Gosselin, F. (2011). Influence of tree characteristics and forest management on tree microhabitats. Biological Conservation, 144, 441-450.

Wagner, S. (2004). Möglichkeiten und Beschränkungen eines funktionsorientierten Waldbaus. Forst und Holz, 59, 105-111.

Wagner, S., Nocentini, S., Huth, F., \& Hoogstra-Klein, M. (2014). Forest management approaches for coping with the uncertainty of climate change: Trade-offs in service provisioning and adaptability. Ecology and Society, 19, 32.

Wagner, S., Wehnert, A., Wong, K. Y., \& Stoyan, D. (2016). Discovering interaction between oaks and carabid beetles on a local scale by point pattern analysis. iForest, 9, 618-625.

Weber, P., Bugmann, H., Pluess, A.R., Walthert, L. \& Rigling, A. (2013). Drought response and changing mean sensitivity of European beech close to the dry distribution limit. Trees, 27, 171-181.

Wedekind, G. W. von (1844). Das Forstwesen im Jahre 1944. In J. von Pannewitz (Ed.), Forstliches CottaAlbum (pp. 288-306). Breslau and Oppeln: Graß, Barth and Comp.

White, J. C., Wulder, M. A., Hermosilla, T., Coops, N. C., \& Hobart, G. W. (2017). A nationwide annual characterization of 25 years of forest disturbance and recovery for Canada using Landsat time series. Remote Sensing of Environment 194, 303-321.

Whitham, T.G., Gehring, C.A., Lamit, L.J., Wojtowicz, T., Evans, L.M., Keith, A.R. \& Smith, D.S. (2012). Community specificity: life and afterlife effects of genes. Trends in Plant Science, 17, 271-281.

Widerberg Koch, M., Ranius, T., Drobyshev, I., Nilsson, U., \& Lindbladh, M. (2012). Increased openness around retained oaks increases species richness of saproxylic beetles. Biodiversity and Conservation, 21, 3035-3059.

Williams, M. (2000). Dark ages and dark areas: global deforestation in the deep past. Journal of Historical Geography, 26, 28-46.

Winter, M.-B., Ammer, C., Baier, R., Donato, D. C., Seibold, S. \& Müller, J. (2015). Multi-taxon alpha diversity following bark beetle disturbance: evaluating multi-decade persistence of a diverse earlyseral phase. Forest Ecology and Management, 338, 32-45.

Winter, M.-B., Bässler, C., Bernhardt-Römermann, M., Krah, F.-S., Schaefer, H., Seibold, S., \& Müller, J. (2017). On the structural and species diversity effects of bark beetle disturbance in forests during initial and advanced early-seral stages at different scales. European Journal of Forest Research, 136, 357-373. 
Winter, S., Flade, M., Schumacher, H., Kerstan, E., \& Möller, G. (2005). The importance of near-natural stand structures for the biocoenosis of lowland beech forests. Forest Snow and Landscape Research, 79, 127-144.

Wohlgemuth, T., Schwitter, R., Bebi, P., Sutter, F., \& Brang, P. (2017). Post-windthrow management in protection forests of the Swiss Alps. European Journal of Forest Research, 136, 1029-1040.

Yue, K., Fornara, D.A., Yang, W., Peng, Y., Li, Z., Wu, F., \& Peng, C. (2017). Effects of three global change drivers on terrestrial C:N:P stoichiometry: a global synthesis. Global Change Biology, 23, 2450-2463.

Zapater, M., Hossann, C., Bréda, N., Bréchet, C., Bonal, D., \& Granier, A. (2011). Evidence of hydraulic lift in a young beech and oak mixed forest using ${ }^{18} \mathrm{O}$ soil water labelling. Trees, 25, 885-894.

Zenner, E. K., \& Hibbs, D. E. (2000). A new method for modeling the heterogeneity of forest structure. Forest Ecology and Management, 129, 75-87.

Zhang, Y., Chen, H.Y.H., \& Reich, P.B. (2012). Forest productivity increases with evenness, species richness and trait variation: a global meta-analysis. Journal of Ecology, 100, 742-749.

Zieger, S.L., Holczinger, A., Sommer, J., Rath, M., Kuzyakov, Y., Polle, A., ... \& Scheu, S. (2017) Beech trees fuel soil animal food webs via root-derived nitrogen. Basic and Applied Ecology, 22, 28-35. 
Fig. 1. Composition of the group (number of people per discipline in parenthesis) and work-flow.

Acting groups

Whole consortium

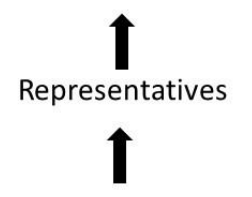

Whole consortium

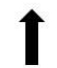

Thematic groups

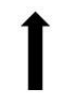

Whole consortium

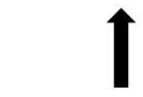

Thematic groups

1

Whole consortium
Group composition

Progress

Manuscript

approval

Forest dynamics (1) Animal ecology (1) Plant ecology (3) Eco-physiology (1)

Vegetation science (1) Disturbance ecology (1) Forest nature conservation (1)

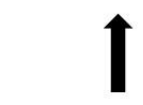

Forest structure

Forest functioning

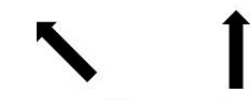

Plenary discussion

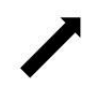

Biodiversity

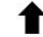

Revision

1

Manuscript

submission

1

Draft version

1

Merging and condensation of key questions

1

Identification of preliminary key questions

Forest dynamics (6) Forest genetics (2) Animal ecology (3) Plant ecology (3)

Vegetation science (4) Landscape ecology (1) Disturbance ecology (1)

Eco-physiology (3) Forest modelling (2) Forest nature conservation (2) 